U.S. Department of Fnergy Office of Inspector General Assistant Inspector General for Audits Washington, DC 20585

\title{
Annual Work Plan for FY 1992
}

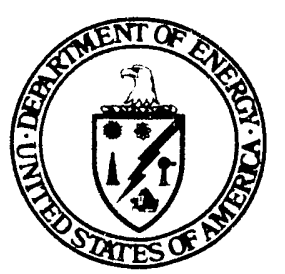

Issue Date: 
This report has been reproduced directly from the best available copy.

Available to DOE and DOE contractors from the Office of Scientific and Technical Information, P.O. Box 62, Oak Ridge, TN 37831; prices available from (615) 576-8401,

FTS 626-8401.

Available to the public from the National Technical Information Service, U.S. Department of Commerce, 5285 Port Royal Rd., Springfield, VA 22161. 
$\mathrm{DOE} / \mathrm{IG}--0010 / 8$

TI92 001929

U.S. Department of Fnergy Office of Inspector General Assistant Inspector General for Audits Washington, DC 20585

\section{Annual Work Plan for FY 1992}

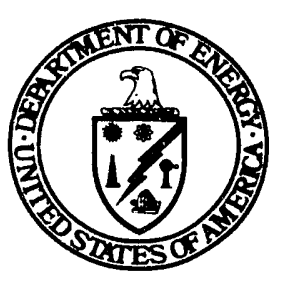

Issue Date:

September 30, 1991

\section{MASTER}




\section{U.S. DEPARTMENT OF ENERGY \\ OFFICE OF AUDIT \\ FY 1992 ANNUAL WORK PLAN}

This plan is hereby published pursuant to requirements of OMB Circular A-73 and DOE 2321.1 .

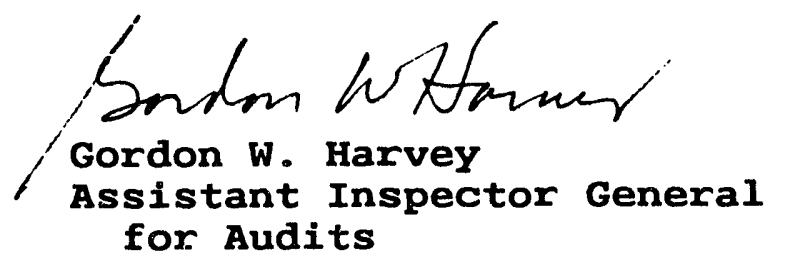

September 30,1991 


\section{TABLE OF CONTENTS}

\section{PAGE}

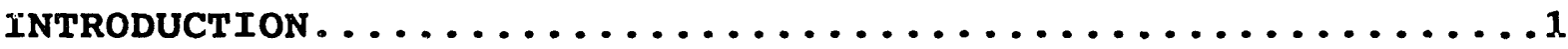

OVERVIEW. ...............................

AUDIT ORGANIZATION CHART.....................

FY 1991 BUDGET OVERVIEW......................

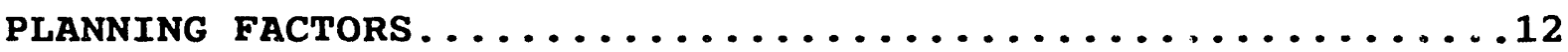

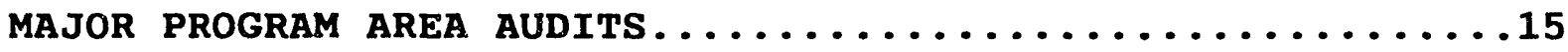

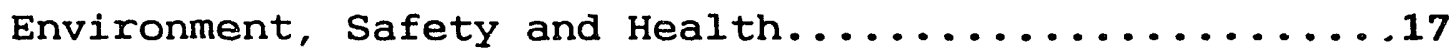

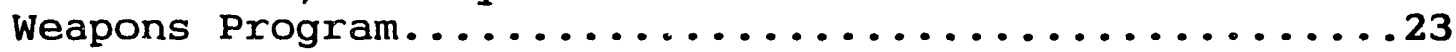

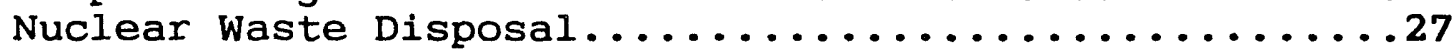

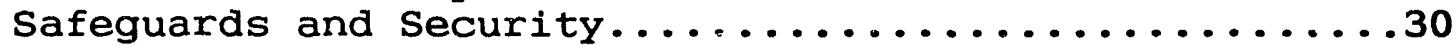

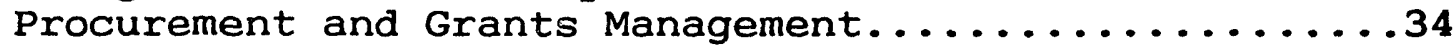

Expansion of the Mission of the Laboratories.........38

Deterrents.............................42

Naval Reactors...........................44

Strategic Petroleum Reserve..................47

Power Marketing Administrations................50

Superconducting Super Collider................56

Financial Management........................59

FY 1990 AUDIT SCHEDULES

Headquarters...........................62

Capital Regional office.....................63

Eastern Regional office......................66

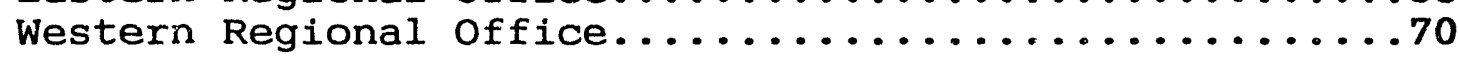

LIST OF ABBREVIATIONS.....................

LIST OF MAJOR ISSUE AREA CODES ................76 


\section{U.S. DEPARTMENT OF ENERGY OFFICE OF INSPECTOR GENERAL OFFICE OF AUDITS}

\section{FISCAL YEAR 1992 ANNUAL WORK PLAN}

\section{INTRODUCTION}

The Office of Inspector General (OIG) has an overall mission to prevent and detect fraud, waste, and mismanagement in Department of Energy (DOE) programs. As part of its responsibility in accomplishing its mission, the DOE Office of Audits publishes an "Annual Work Plan" in September of each year. The prime focus of the plan is to identify opportunities for audits to enhance the effectiveness, efficiency, and integrity of the DOE's programs and operations. Through this plan, we are able to maximize the effectiveness of our resources and to avoid duplicating audit coverage being provided by other audit groups, such as the U.S. General Accounting Office (GAO) to U.S. Department of Energy programs. Such planning is required by Office of Management and Budget Circular A-73 and DOE Order 2321.1A.

The work planning process continues to evolve over the course of the year. In an ideal planning environment, the plan would represent a program of audit starts and completions for the year with little room for deviation. Experience shows, however, that such a planning environment rarely exists in an organization where audit resources axe limited, external oversight is extensive, and departmental priorities are in a state of redefinition.

This work plan, includes those audits that are to be carried over from Fiscal Year 1991 and those that are to be started during Fiscal Year 1992. Audits identified in this plan will be performed by OIG audit staff, as supplemented by contracted audit services. Internal auditors of the Department's integrated contractors provide additional audit coverage, and, to the extent possible, their efforts are coordinated with those of the Inspector General. Audits are also conducted by the GAO, which has independent external audit authority over the Department's programs, and the Defense Contract Audit Agency and Department of Health and Human Services, both of which provide contract audit services to the Department on a reimbursable basis. 
The Office of Inspector General was established by the Department of Energy organization Act of 1977 to provide audit, investigative, and related services to the Department. Under the Act, the Inspector General is responsible for audits and investigations and for recommending policies for the purpose of promoting economy and efficiency in the administration of, and preventing and detecting fraud and abuse in, the programs and operations of the Department. The office of Audits is responsible for performing independent audits of all DOE programs.

The basic mission of the OIG remains unchanged by enactment of the Inspector General Act Amendments of 1988, P.L. 100-504, which, effective April 16, 1989, placed the DOE OIG under the authority of the Inspector General Act of 1978, as amended, 5 U.S.C., App. 3 .

The Office of Audits also issues audit policy and guidance to other Departmental elements, and is responsible for assuring that all audit work done in the Department, including that done by the integrated contractors, meet Government Audit standards or the audit standards issued by the Institute of Internal Auditors.

Three Assistant Inspectors General (AIG's) report directly to the Inspector General. They include AIG's for Inspections, Investigations, and Audits. The current organization of the office of Audits is shown on the following page. 


\section{Department of Energy \\ Office of Assistant Inspector General for Audits}

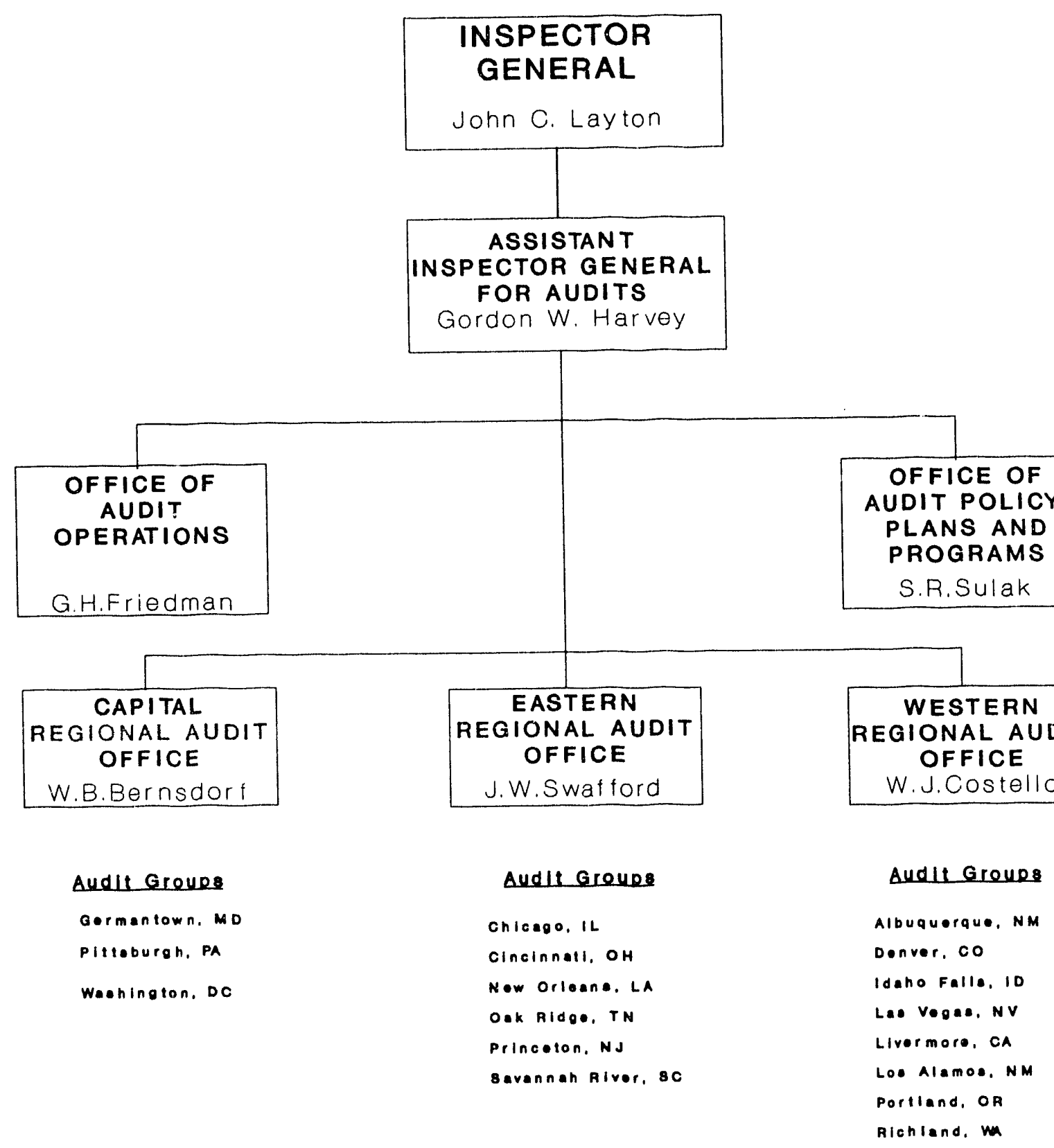




\section{FY 1992 DOE BUDGET OVERVIEW}

The work planning strategy for the Office of Audits has for a number of years been driven by the overall budget of the Department. As such it is important to keep in mind the size of DOE, the nature of DOE's mission and the budget for that mission.

There are almost 160,000 personnel working at DOE facilities throughout the country (see map on p.11) employed either directly or indirectly by the DOE. Approximately 141,000 of the employees work for the contractors that operate the Department's laboratories and industrial facilities. The remaining employees are Federal workers who, among other things, provide administrative services and programmatic and management direction of the work done for the DOE by its operating contractors.

The Department's FY 1992 budget is being presented in a structure that ties directly to the recently announced National Energy StrategY (NES). The NES, which was announced by President Bush in February 1991, is based on public input through hearings, written submissions and publicly available reports; all of which were aimed at reconciling our need for secure, competitively priced supplies of energy with envirorment, safety and health requirements. To be meaningful, the findings of the National Energy strategy must be integrated into the Department's budget. The iJES concentrates on energy issues and does not, therefore, encompass all of the activities of the Department, which has major defense and scientific missions as well as a large management oversight function to perform.

Following is a brief overview of the NES areas making up the FY 1992 budget request:

- Enhancing Environmental Quality - includes all activities associated with environment, safety and health, such as waste management operations, environmental restoration, technology development, corrective activities, and policy and management. Also included in this area are all activities dealing with nuclear waste disposal such as Civilian Radioactive Waste Research and Development and the Nuclear Waste Fund. The FY 1992 request for new funds is about 10\% higher than the FY 1991 estimate. This area accounts for slightly more than 25\% of the total FY 1992 budget request of the Department.

o Increasing Energy Efficiency - includes activities dealing with energy conservation and efficiency improvements in homes, buildings, transportation and industry. The FY 1992 budget request is almost 50\% higher than the FY 1991 
Activities related to increasing energy efficiency represent about $1.6 \%$ of the Department's FY 1992 request.

- Securing Future Energy Supplies - is directed at assuring that future U.S. energy supplies are adequate. Activities include basic research and applied technology development aimed at developing alternatives to imported oil, including fusion energy, and promoting increased use of domestically available resources, including oil, gas, coal, nuclear and renewable energy. Activities related to the Power Marketing Administrations, Strategic Petroleum Reserve, Naval petroleum and oil shale Reserves, and efforts to increase the efficiency of electric energy distribution and storage are also included in this area. Although the FY 1992 request is about 108 lower than the FY 1991 estimate, this area accounts for almost $13 \%$ of the Department's FY 1992 budget request.

o Fortifying Foundations - deals with maintaining the United states' preeminence in the scientific and technical arenas and, as a consequence, its economic competitiveness in the world. DOE funds basic research and development at its National Laboratories, at universities, and in corporations to maintain this preeminence. The Department is also committed to improving science and mathematics education in the United states and transferring technologies developed by the Department into the commercial marketplace. Major activities include basic and applied research and development in high energy physics, nuclear physics, the superconducting super collider, basic energy sciences and biological and environmental research. The FY 1992 budget request is about $16 \%$ higher than the FY 1991 budget estimate, and accounts for over $14 \%$ of the FY 1992 budget request.

- Meeting National Defense Needs - includes a variety of activities that contribute to national security through DOE's defense programs and through certain non-defense activities in preparation for potential energy emergencies. Included in this category are areas such as weapons activities, materials production, new production reactors, verification and control technology, safeguards and security, and the Naval Reactors program. The FY 1992 budget request is about 1 of lower than the FY 1991 budget estimate. However, Meeting National Defense Needs accounts for the largest share of DOE's FY 1992 budget request, over $43 \%$.

- Management and Other Activities - includes conservation grants, activities of the Energy Information Administration, administering energy laws and regulations, and Departmental management. This year's budget request represents a 37용 decrease from the FY 1991 estimate, and 
accounts for slightly more than 28 of the total FY 1992 DOE budget request.

The following table compares the funding request for FY 1992 with the estimated FY 1991 funding levels by the major goals identified in the NES. The accompanying graph indicates the relative portions of the FY 1992 budget accounted for by each of the NES areas.

DOE BUDGET REQUEST

BY MAJOR GOALS

Major Goals of the Department of Energy

Enhancing Environmental Quality

Increasing Energy Efficiency

Securing Future Energy Supplies

Fortifying Our Foundations

Meeting National Defense Needs

Management and Other Activities

Subtotal

Proposed FY 1991 Supplemental

Total, Department of Energy

Budget Authority

(in Billions)

FY 1991

FY 1992

Estimate

Request

$\$$

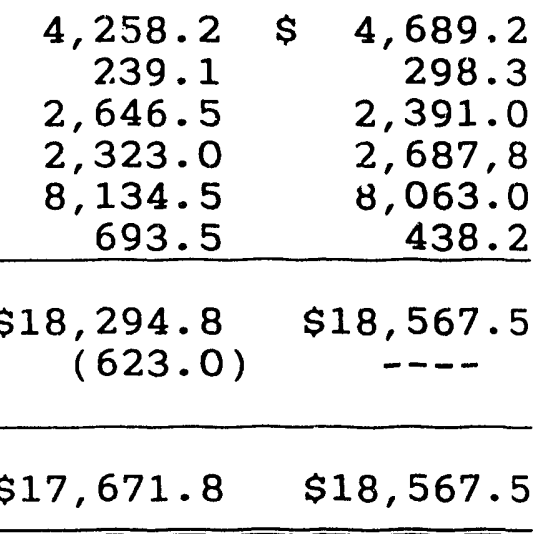




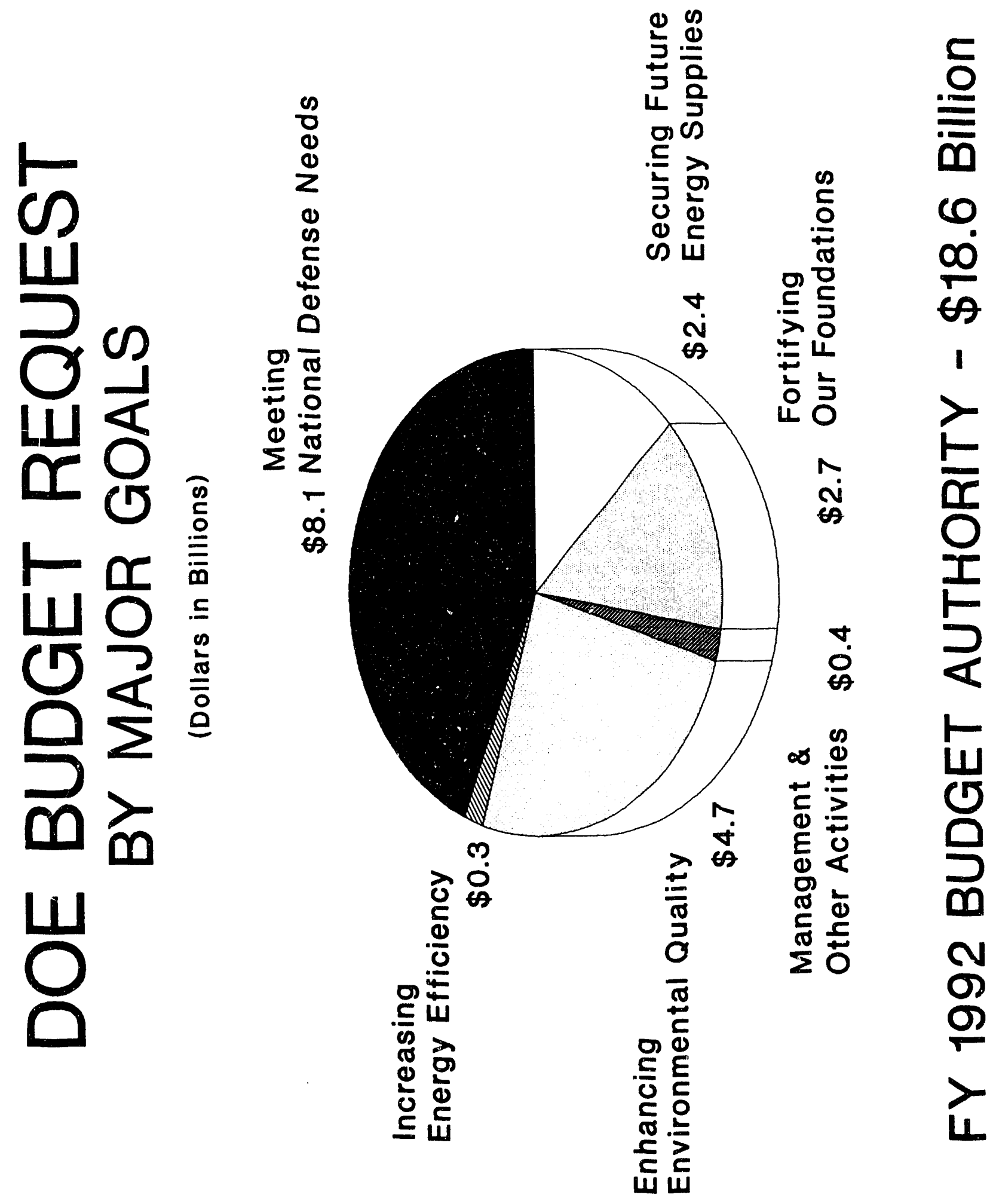


The following table provides a more detailed look into the Department's FY 1992 budget request and compares this request to FY 1991.

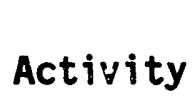

FY 1991

Comp

(000)
FY 1992

Departmental

Request

(000)

\section{Atomic Energy Defense}

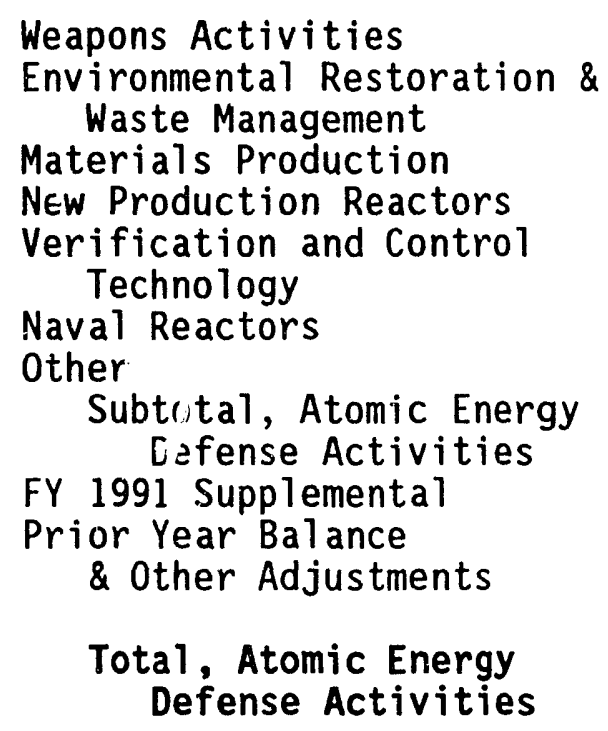

Weapons Activities Waste Management

Materials Production

NEW Production Reactors

erification and Contro

Technology

Naval Reactors

Subti

total, Atomic Energy

Cefense Activities

$\$ 4,621,099$
$3,455,737$

$1,951,333$

375,000

154,529

769,801

212,634

$\$ 11,540,133$

(623,000)

50,000

$\$ 10,967,133$

\begin{tabular}{rrr}
$\$ 4,476,500$ & $-3.1 \%$ \\
$3,705,000$ & + & $7.2 \%$ \\
$1,876,900$ & $-3.8 \%$ \\
$500,000+$ & $+33.3 \%$ \\
$185,000+19.7 \%$ \\
$801,000+4.1 \%$ \\
$223,600+5.2 \%$ \\
\hline
\end{tabular}

$\$ 11,768,000$

$\$ 11,768,000+73 \%$

\section{Energy Supply R\&D}

\author{
Solar \& Other Renewables \\ Wuclear R\&D Activities \\ Biological and \\ Environmental Research \\ Fusion Energy \\ Basic Energy Sciences \\ Environment, Safety and \\ Health \\ Environmental Restoration \\ and Waste Management \\ other \\ Prior Year Balance \\ \& Other Adjustments \\ Tota1, Energy Supply \\ R\&D
}

$\$$

129,418
304,996

368,629

273,557

711,760

129,057

431,356

228,339

$\$(54,712)$

$\$ 2,522,400$
$\$ 142,878+10.4 \%$

$397,958+30.5 \%$

$312,560-15.2 \%$

$337,100+23.2 \%$

$714,700+0.4 \%$

$159,670+23.7 \%$

$523,495+21.4 \%$

$233,067+2.1 \%$

$\$ 2,821,428+11.9 \%$ 
General Science \& Research

High Energy Physics

Superconducting Super Collider

Nuclear Physics

Program Direction

$$
\begin{array}{rrr}
\$ 588,587 & \$ 666,449+13.2 \% \\
242,866 & 533,700+119.8 \% \\
313,329 & 342,390+9.3 \% \\
3,950 & 6,400+62.0 \% \\
\hline
\end{array}
$$

Total, General Science $\$ 1,148,732 \$ \$ 1,548,939+16.5 \%$ \& Research

\title{
Fossil Energy Research \& Development
}

$$
\begin{aligned}
& \begin{array}{lrrrr}
\text { Coal } & \$ 289,066 & \$ & 115,010 & -60.2 \% \\
\text { Environmental Restoration } & 708 & & 8,085 & +1041.9 \% \\
\text { Unconventional Gas Recovery } & 15,890 & & 8,000 & -49.7 \% \\
\text { Petroleum } & 59,033 & & 52,175 & -11.6 \% \\
\text { Other } & 98,727 & & 43,735 & -55.7 \% \\
\quad \text { Subtotal, Fossil Energy } \$ & 463,424 & \$ 227,005 & -51.0 \%
\end{array} \\
& \$ 458,750 \quad \$ 22,, 005-50.5 \%
\end{aligned}
$$

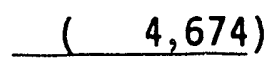

Power Marketing

Administrations

$$
\$ 488,189 \quad \$ 265,494 \quad-\quad 45.6 \%
$$

Nuclear Waste Fund

$$
\$ 242,833 \$ 305,071+25.6 \%
$$

Clean Coal Technology

$$
\$ 391,000 \quad \$ 315,000-19.4 \%
$$

Other Departmenta1

$$
\$ 1,452,730
$$

$\$ 1,316,609$

$9.4 \%$

\author{
Activities
}

\section{Total Department

$$
\text { of Energy }
$$

$$
\$ 17,671,767
$$

$\$ 18,567,546+$

$5.1 \%$

Source: United States Department of Energy Posture Statement and Fiscal Year 1992 Budget Overview 


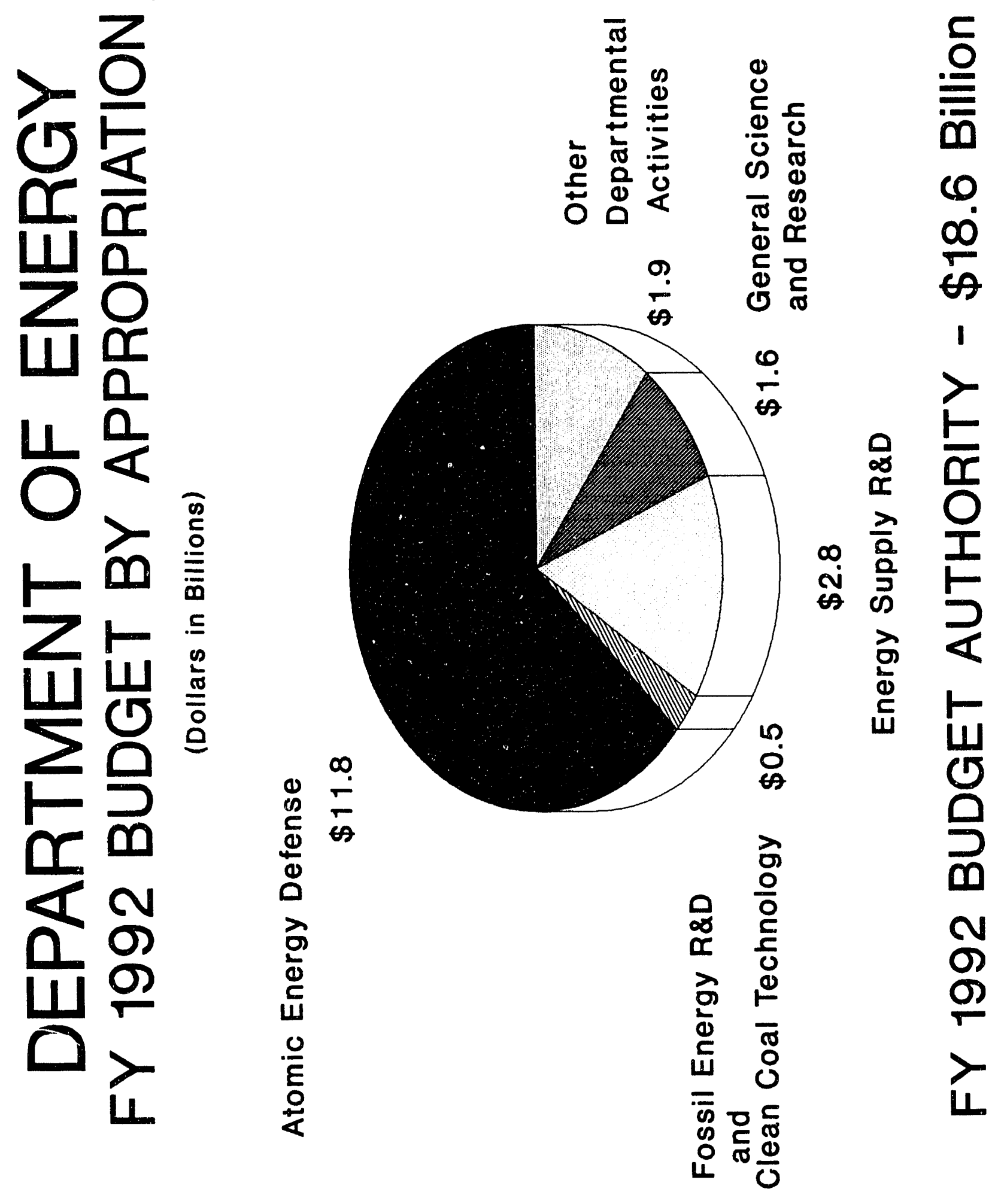




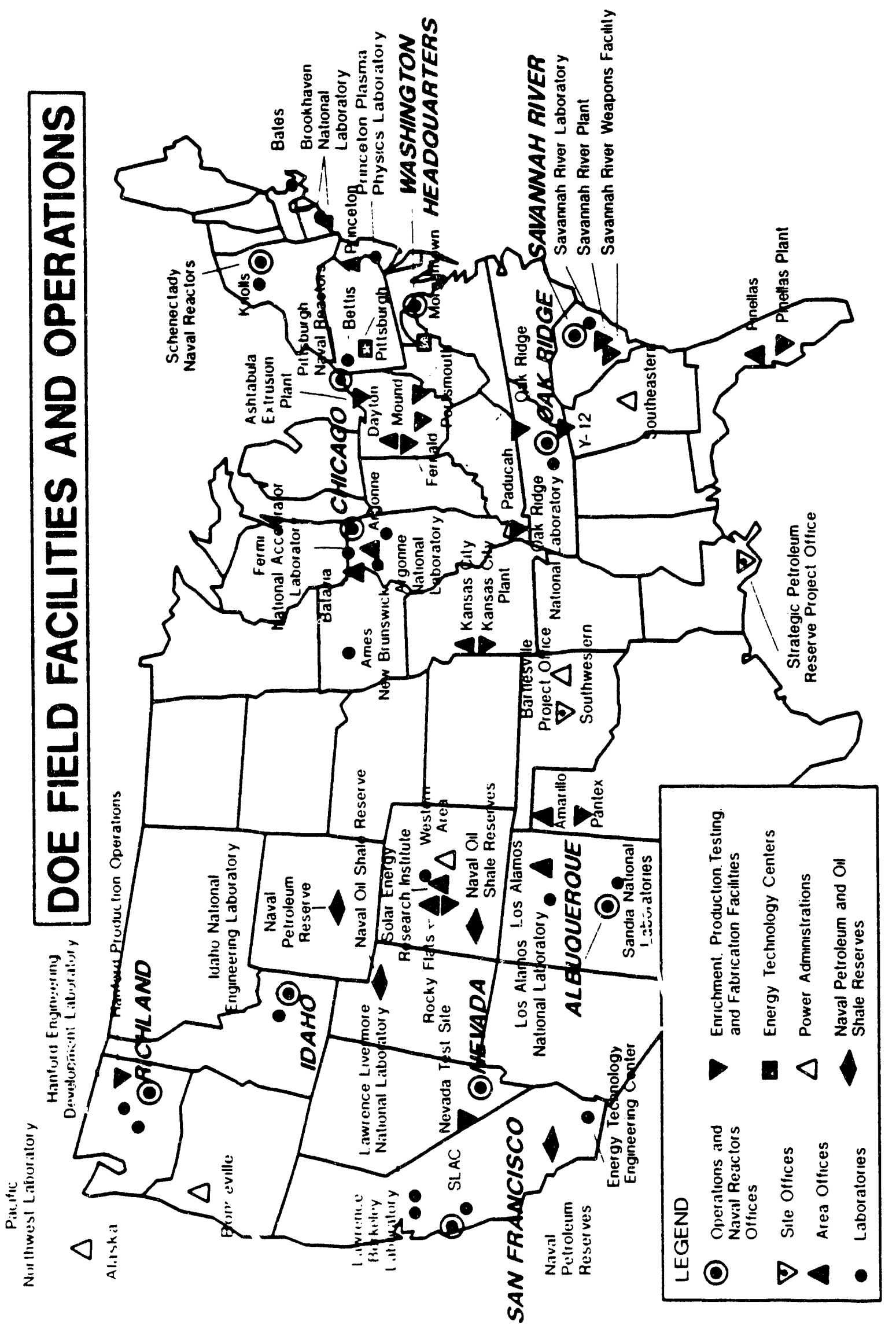


PLANNING FACTORS

There are many distinct factors that effect the planning effort. They may be broken out by both external factors and internal resource factors. The following summarizes those factors that had a significant impact on the planning for FY 1992.

\section{EXTERNAL FACTORS}

The audit planning process is primarily driven by budget and program policy issues. Each year a planning document is issued which provides guidance based on review and analysis of the budget request, financial trend data, and the current audit environment (including both OIG audit planning and significant audit or audit-like activities conducted by Department personnel and/or external entities). Additional guidance was obtained through the review of the United states Department of Energy Posture statement and Fiscal Year 1992 Budget Overview, issued in February 1991, and the National Energy Strategy final report.

In FY 1990 the office of Audits identified 12 major issue areas and began developing a strategy to provide coverage of these areas over a 3 to 5 year period. These areas continue to be the principle focus of the FY 1992 work Plan. They include:

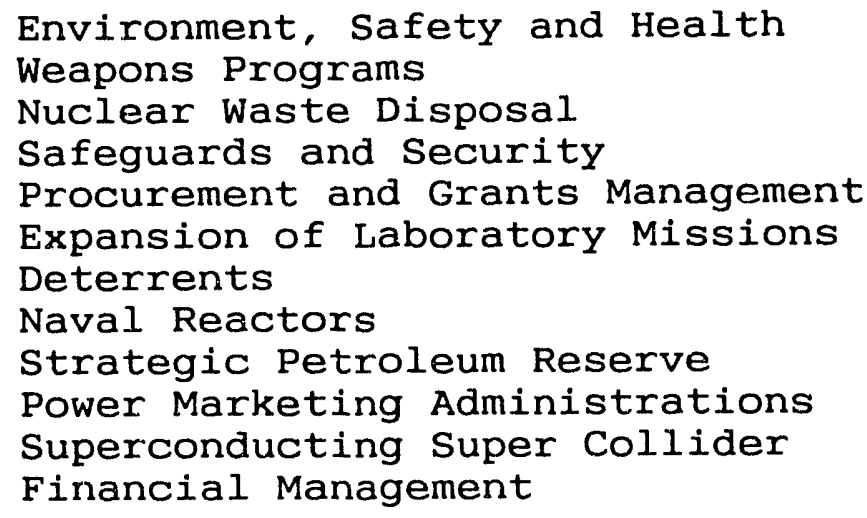

In planning the use of our audit resources for FY 1992, we considered those activities which the office of Audits must perform, such as audits required by the Federal Managers' Financial Integrity Act, audits of Year-end spending activities within the Department, and financial audits of the Department's integrated contractors. Remaining resources were then allocated to the 12 major issue areas. In January 1991, the Defense Contract Audit Agency (DCAA) assumed the responsibility for all but a limited number of contract preaward and cost incurred audits for the Department. 
Some of the audit approaches to the issues are program oriented, while others require a functional or organizational approach. One of the areas that utilizes the organizational approach is the area of "Deterrents." This area concentrates on those issues crosscutting both programs and functions that are most vulnerable to fraud, waste, or mismanagement. Many of these audits involve integrity of employees and procurement related issues. It is also anticipated that leads for investigations will be generated from this issue area.

Another area of activity that lends itself to the functional/organizational approach is our audits of the integrated contractors. Beginning in FY 1988, the Office of Audits began cooperative audit efforts with the internal auditors at the Department's integrated contractors. An integrated contractor is defined as one whose costs under a cost-type contract are prefinanced by DOE and is required to maintain a separate and distinct system of accounts, records, documents, and other evidence supporting all allowable costs incurred, and revenues or other applicable credits. The system of accou.ts employed by the contractor must be satisfactory to DOE and in accordance with generally accepted accounting principles consistently applied unless DOE requires the use of an alternate accounting policy or procedure.

The Office of Audits has issued an Audit Manual that, in part, defines the Office's policies and procedures pertaining to audits of the Department's integrated contractors, and provides guidance for auditing them. Fundamentally, the policy is that every significant function of a contractor's operations will be audited at least once every five years.

The true level of effort we will expend in auditing integrated contractors is difficult to measure because many of these audits will cross over to the other major program areas previously identified and many of the major program area audits will involve the integrated contractors.

\section{STAFFING FACTORS}

\section{Contracted Audit support.}

Fiscal Year 1992 will be the ninth full year that the OIG will be using contracted audit support to assist in accomplishing its audit mission. Although the use of contractors has enabled the Office of Audits to provide the DOE more extensive audit coverage, it does require a substantial commitment of in-house resources to prepare for and maintain effective use of these external resources. 


\section{Restructuring.}

During FY 1991, the office of Audits underwent a significant restructuring in terms of resource mix and location of audit staff. The amount of contracted audit resources declined, additional staff (primarily entry level recent college graduates) were hired and several new offices were opened. As a result of opening offices in Pittsburgh, PA, Cincinnati, OH, New Orleans, LA, Los Alamos, NM, and reactivating our office in Richland, WA, many staff reassignments were required. Additionally, new managers were hired who were unfamiliar with the Department's programs and activities.

The loss of services of experienced contracted auditors, the hiring of traineee level auditors and those unfamiliar with the Department, along with the reassignment of experienced personnel, has had a negative impact on audit productivity during FY 1991 . Also, as noted above, preaward and cost incurred audits are now being performed primarily by the DCAA. These audits were usually of short duration, averaging about 36 days each, and totalled 160 reports in FY 1990, the last full year of IG activity in this area. These factors all contributed to a reduced number of reports being issued in FY 1991.

Although some restructuring will continue in FY 1992 , productivity should rebound as a result of the new personnel gaining experience and familiarity with the Department. We plan to continue our move away from contracted audit support, hire additional staff, and open additional offices that will enable us to provide more responsive audit coverage of Departmental activities.

This work plan has attempted to anticipate the restructuring of operations during FY 1992, but at the time the plan was published, many budgetary unknowns exist for both FY 1992 and FY 1993 which could have a direct impact on staffing and restructuring in FY 1992. Our plans for this year will be adjusted as our budgetary picture becomes clearer. 
As noted above, 12 major program areas have been identified for intensive coverage over the 3 to 5 year period that began with FY 1990. Our long-range plan and the current year's distribution of flexible resources are shown in the following table. Note that "flexible" refers to the timing and selection of necessary audits during the period covered by this work plan. It does not mean that the work to be performed is optional in nature.

Percentage of Flexible Assets

Long-Range Plan FY 1992

Environment, Safety

\& Health

Weapons Program

$55 \%$

33.68

Nuclear Waste Disposal

safeguards \& Security

Procurement \& Grants

Management

Expansion of Laborator

Missions

Deterrents

$25 \%$

$23.5 \%$

Naval Reactors

Strategic Petroleum

Reserve

Power Marketing

Administrations

$20 \%$

42.98

Superconducting Super

Collider

Financial Management

The heavy emphasis placed on the third group includes the new audit requirements created by the Chief Financial officers Act of 1990 (P.I. 101-576). This accounts for over 12 staff years, or almost one-forth of this groups time.

Although projects are only identified with one major program area for planning purposes, many overlap into one or more additional program areas. For example, an audit of the strategic Petroleum Reserve (one of our major program areas) may overlap with 
Safeguards \& Security or Environment, Safety \& Health. Thus coverage in some areas may be understated for purposes of this plan.

Beginning on page 17 is a summary of each major program area and the OIG level of audit effort. Details of the Office of Audits Fiscal Year 1992 work plan follow the summaries. 


\section{ENVIRONMENT, SAFETY, AND HEALTH}

\section{BACKGROUND}

During the past several years, the issues of Environment, Safety, and Health (ES\&H) have become major concerns in the Department because of their visibility outside the Department and because of theil far reaching and expensive consequences. The Department has requested $\$ 5.32$ billion for FY 1992 to address the areas of Enhancing Environmental Quality, Biological and Environmental Research, and Clean Coal Technology.

While these are not new problem areas, they are receiving greater attention than in the past. Since the $1940^{\prime} \mathrm{s}$, nuclear production facilities and other activities of the Department have released hazardous and radioactive contaminants into the air, water, and soil. In the past, the Department and its predecessor agencies claimed exemption from most environmental laws. Today, much stricter compliance requirements have been placed on the Department due to more recent interpretations of older laws, the advent of new laws and regulations, and increased public concern.

Within the Department, responsibility for complying with environmental, safety, and health standards is shared among the Office of Environmental Restoration and Waste Management; the office of Ervironment, Safety, and Health; Departmental Headquarters Program Offices; DOE Field Offices; Power Markeiing Administrations; the National Renewable Energy Laboratory; and the contractors and subcontractors which operate the Department's facilities.

\section{Enhancing Environmental Quality}

The Department plans to spend tens of billions of dollars over the next few decades to repair the well publicized environmental damage that has occurred at its facilities. Although the Department has taken the first steps toward bringing its facilitjes into compliance with environmental laws, the bulk of the work remains to be done.

Environmental Restoration and waste Management is the fastest growing program area in the Department. Its Five-Yeir Plan is the cornerstone of the Department's long-term strategy to consulidate and coordinate the Department's cleanup activities. The Five-Year Plan combines cleanup activities in the areas of Defense Programs, Nuclear Energy, and Energy Research; treats them as a unified program; and establishes an agenda for compliance and cleanup against which progress will be measured. For FY 1992, 92 percent of the Environmental Restoration and Waste Management budget is related to compliance and cleanup 
activities that are conducted pursuant to environmental laws and regulations. The remaining 8 percent of the Administrations' budget request would fund the Technology Development, Transportation Management, or Program Direct accounts.

ES\&H Oversight activities include independent, internal, and routine monitoring and management oversight to ensure that facilities are operated consistent with applicable Departmental orders and external regulatory requirements. This category includes the oversight functions of the office of Environment, Safety, and Health; and the office of Nuclear Safety, which continuously assesses both Departmental and contractor nuclear safety performance.

Juclear Waste Disposal includes all activities directed toward the ultimate disposal of spent nuclear fuel and high-level radioactive waste, including a small research and development program.

Biological and Environmental Research (BER)

The BER program provides the scientific foundation for (1) the understanding of the long-term health and environmental consequences of energy use and development, and (2) solutions of major biomedical and environmental problems. The program gives particular emphasis to the development and application of biotechnology to fulfill Departmental objectives and reflects the priorities developed in the National Energy Strategy process.

The program includes several areas of scientific research:

- analytical technology involving development of advanced instrumentation and dosimetry capability (\$13.3 million);

o environmental research, including atmospheric, marine and terrestrial research activities (\$36.9 million);

o health effects research, investigating the health impact of radiation and energy related chemical exposure ( $\$ 36.6$ million);

- general life sciences research, involving fundamental cellular and molecular level studies, including human genome research ( $\$ 90.9$ million); and

o medical applications studies to develop advanced techniques for the application of radiation and radionuclides for diagnosis and therapy ( $\$ 33.9$ million).

A major element of the program is directed toward gaining a better understanding of global change. BER's contribution to the Department's global climate change research program ( $\$ 77.0$ million) is an integral part of the U.S. Global Change Research 
Program (USGCRP) which is developed and coordinated by the Committee on Earth and Environmental Sciences. Nine agencies have joined forces to create the USGCRP which has become a paradigm of interagency cooperation and a model for the international collaboration to address this potentially serious environmental problem.

The $\$ 312.6$ million requested in FY 1992 for Biological and Environmental Research is a significant reduction from the programs $\$ 368.6$ million estimated budget in FY 1991 .

\section{Clean Coal Technology}

Clean Coal Technology is a multi-phase demonstration program almed at introducing innovative methods of burning coal more cleanly, efficiently, and economically. Technologies demonstrated under the program wili substantially reduce emissions of sulfur-dioxide and nitrogen oxides (precursors to acid rain) and carbon dioxide (a greenhouse gas). This program requires industry to share at least 50 percent of the cost, and provides for recoupment of public investments from major commercial successes. So far, the industrial share has exceeded 60 percent for the 35 projects which are currently part of the program.

The Clean Coal Technology demonstration program will take the best, most promising, and efficient of the advanced coal-based processing and emissions control technologies, and over the next decade move them from the proof-of-concept stage into the commercial marketplace through demonstration. By building and operating these first-of-a-kind plants, industry will be in a position to obtain the necessary data on construction and operating costs, reliability, maintenance, and environmental performiance to make the necessary deployment decisions for the 1990 s and beyond. The success of this program will play an important role in meeting electric power demand under the new Clean Air ACt amendments and in addressing concerns over potential global climate change.

The $\$ 315.0$ million requested in FY 1992 for Clean Coal Technology is a significant reduction from the programs $\$ 391.0$ million estimated budget in FY 1991 .

\section{LEVEL OF EFFORT}

The FY 1991 work plan anticipated that about six staff years would be spent auditing ES\&H activities, and through the first ten months of the year, over five and one-half staff years had been expended. Reports issued during FY 1991 include the following: 
- Environmental Compliance By Brookhaven National Laboratory

(ER-B-91-05, November 30, 1990) where we evaluated policies, procedures, and practices for complying with environmental laws and for identifying the need for and obtaining necessary permits. We found that the contractor did not adequately document the training of personnel needed for job performance and the actual training completed by employees handling hazardous waste. Also, policies, procedures, and controls were not adequate for obtaining and complying with permits as the contractor operated a landfill after its permit expired, and emitted pollutants without obtaining permits. Our recommendations to improve control.s were concurred in by the officials to which the report was directed.

- Environmental Training at the Department of Energy (DOE/IG-0294, December 1990) where we found that individuals involved in hazardous waste operations at DOE facilities were not ieceiving training required by Federal environmental laws and DOE Orders. This occurred because DOE Operations Offices had not provided their management and operating contractors with sufficient guidance and direction to ensure compliance with onvironmental training requirements. In addition, contractors did not have adequate systems to identify employees requiring training, to ensure that the training was received, and to effectively document compliance with Federal and DOE requirements. Noncompliance with applicable statutory requirements leaves the Department vulnerable to possible enforcement actions, loss of credibility, and increased risks to worker health and safety. Management concurred.

- Audit of Testing Laboratory Support to the Environmental Survey Program (DOE/IG-0293, December 1990) in which we sought to determine whether laboratory support for the environmental survey program was performed in accordance with provided procedures. We found that 43 percent of the laboratory tests on organic samples exceeded standard maximum holding times, and 31 percent of the organic samples were tested when the laboratories had received failing test scores which, under Environmental Protection Agency (EPA) criteria, should have disqualified them for further testing. Also, deficiencies found by the EPA were not being corrected. These conditions apparently existed because adequate policies and oversight were not established to ensure adherence to DOE's quality assurance program. Management did not take corrective actions until January 1989, when the analysis program was essentially complete. 
The primary concern of the report is securing credible results in future testing endeavors. Management believes actions being taken will mitigate the sampling and analysis problems noted in our report.

- Management of Trichloroethane, Bonneville Power Administration (WR-B-91-3, January 9, 1991) in which we examined management of the solvent 1,1,1-trichloroethane (trichlor). We found that although acceptable substitutes existed, management continued to use trichlor, a hazardous substance regulated by the Resource Conservation and Recovery Act and the Safe Drinking Water Act, at Bonneville substations, and steps were not taken to minimize hazardous waste associated with trichlor. We recommended and management agreed to develop standards for the use of trichlor.

- Department of Energy's Waste Minimization Program (DOE/IG-0298, september 1991) where we found that, while waste minimization progress is being made in the Department, significant opportunities to eliminate or minimize radioactive and hazardous wastes still exist. Opportunities for minimizing waste, which, if implemented, could have immediate and substantial effect in reducing waste, were not being implemented because of limited use of incentives, minimal program guidance, and funding uncertainties. Potential savings could reach approximately \$30 million.

For FY 1992, the Office of Audits plans to spend over 12 staff years on ES\&H audits. Several audits currently in process, will be carried over to FY 1992 including:

- an audit of "Bonneville Power Administration's (BPA's) Environmental Training" designed to determine whether BPA has designed and implemented environmental training programs that comply with the requirements of environmental regulations.

- a Department-wide review of coordination and technology transfer between environmental cleanup projects at different sites that address the same basic waste problem, such as processing transuranic waste, vitrification, or monitoring ground water.

- a review of occupational medical programs at Department of Energy sites to determine whether these sites comply with Federal and/or Departmental occupational medical program requirements. 
Included in new reviews scheduled to start in FY 1992 are the following:

- review of the Remedial Action/Feasibility Study at ORNL. The stuá, to be reviewed identifies what is to be cleaned up and the approach to be employed.

- a review of waste processing programs at selected Departmental Field offices and operating contractors.

- four follow-up audits will determine if recommended corrective actions to environmental findings made by Departmental review teams have been implemented. These audits will be performed at the Brookhaven National Laboratory, the Argonne National Laboratory, the Lawrence Berkeley Laboratory, and the Rocky Flats plant.

- a survey of environmental activities at the Hanford Site in Washington state.

o a revier of the management of the Hazardous Waste Remedial Action Program by Martin Marietta Energy Systems, Inc.

o a review of the West Valley Demonstration Project to determine if west Valley Nuclear Services, Company, Inc. is achieving it's planned results. 


\section{WEAPONS PROGRAM}

\section{BACKGROUND}

The weapons program is essential to the sacurity of the United states, and accounts for almost one-fourth of the Department's total FY 1992 budget request. The budget for the weapons program is included in the Department's appropriation for Atomic Energy Defense Activities, which comprises over $63 \%$ of the FY 1992 budget request. Many of the other activities included in this appropriation relate either directly or indirectly to weapons activity, such as materials production, safeguards \& security, new production reactors, and the Naval Reactors program. As a result, the true impact of weapons activities is more substantial than it may first appear.

The mission of the Department's weapons activities is to support the national security policy of nuclear deterrence. The defense program is complex, involves many offices and contractors within the Jepartment, and must be closely coordinated with the Department of Defense.

Because many of the program's facilities are old, their operating availability and efficiency have declined. These problems are especially evident in the Department's nuclear production reactors, which are the nation's sole source of new nuclear material for defense. Associated with these conditions are several serious environmental, health, and safety concerns. Modernization of the aging weapons complex and restoration of sites to make them safe, viable facilities is one of the largest single tasks facing the Department.

Major components of the weapons program include:

o Weapons Research, Development, and Testing activities to develop new nuclear weapons, advance the state-of-the-art of weapons technology, transfer nonsensitive defense technology to the private sector, monitor the nuclear weapons stockpile to assure continued reliability and effectiveness, support the Strategic Defense Initiative, and advance inertial fusion technology.

- Weapons production and Surveillance activities include procurement of materials, fabrication and assembly of new nuclear weapons and weapon components, life-time maintenance and reliability assessment of the existing stockpile, development and operation of safe-secure systems for transporting nuclear weapons and components, upgrading of safety and environmental activities in order to resume operations at the Rocky flats plant, 
and support of the programmatic environmental impact statement for the weapons complex reconfiguration.

- Materials Production provides the nuclear materials to meet national defense requirements by operating production reactors, reactor feed materials production facilities, spent fuel chemical processing plants, and othe: facilities.

Production and environmental problems within the Weapons Complex are among the Department's top priorities. These problems have limited the Department's ability to effectively and efficiently design, test, produce and maintain nuclear weapons. Major problems facing the Department include:
o resuming production operations at the Rocky Flats Plant;
o restarting nuclear materials reactor operations;
o restoring the environment at several sites; and
o safely disposing of large accumulations of radioactive waste.

The Assistant Secretary for Defense Programs at Headquarters provides management direction, which is carried out primarily by the Office of Military Applications and the office of Nuclear Materials.

The DOE Field office, Albuquerque, plays a major role in coordinating weapons production activities. Other Field Offices with substantial participation in defense programs include Nevada, Savannah River, Richland, Idaho Falls, Oak Ridge, and San Francisco.

Weapons research is performed by the Los Alamos National Laboratory in New Mexico, Lawrence Livermore National Laboratory in California, and Sandia National Laboratories in New Mexico and California. Other national laboratories and research facilities also participate. Major facilities involved in nuclear materials production are located in South Carolina, Ohio, Washington, and Tennessee.

\section{LEVEL OF EFFORT}

Because of the large percentage of the Department's budget spent on the weapons program and the program's importance to national defense, the office of Audits has historically allocated a substantial portion cf its resources to auditing the Weapons Program. Through the first ten months of FY 1991, about seven staff years of time had been spent on audits of this area. Substantial amounts of time have also been spent on audits 
related to the weapons program as discussed above and in other sections of the work plan.

Reports issued during FY 1991 included:

- Travel and Per Diem Reimbursement on the Price Waterhouse Subcontract at the Savannah River site (ER-B-91-12, February 1, 1991) where the objective was to determine the adequacy of Savannah River Operations office and Westinghouse Savannah River Company's (WSRC) policies, practices, and procedures for controlling travel costs on Price Waterhouse and Company subcontracts. We found that WSRC reimbursed Price Waterhouse for $\$ 23,200$ of unallowable and $\$ 225,000$ of unreasonable travel and per diem costs. Management concurred with our recommendations for corrective action.

- Construction Carrying Account at the Savannah River Site (ER-B-91-14, March 14, 1991) where the objective was to determine if the Construction Carrying Account was being used for the purpose intended and if the costs that flowed through the account were appropriate. We found that the account was being used improperly to accumulate and allocate costs of both operations and construction activities. Management generally concurred with our recommendations.

- Departmentwide Audit of the Visibility over the status of Nuclear Materials (DOE/IG-0296, August 1991). The purpose of this audit was to determine the accuracy of assessment reports on the status of nuclear materials at selected DOE facilities. We found that assessment reports for nuclear materials inventories were not always accurate, valid, or complete, primarily due to a lack of Headquarters guidance and limited emphasis in inventory assessments of contractor materials management programs.

In FY 1992, the Office of Audits plans to spend over 14 staff years on Weapons Program audits. Audits currently in process that will carry over to FY 1992 include:

- "Savannah River Site Central Shops" intended to determine whether central shop operations are consistent with mission needs, are managed economically, and are assigned proper overhead rates.

- "Site Development Plan at the Y-12 Plant" designed to determine whether the Y-12 Plant has a site development plan prepared in accordance with DOE Order 4300.1B.

Some of the audits that are currently planned to start in FY 1992 include: 
- a survey of the component reliability testing program which will look at the practices and procedures related to laboratory and flight testing of weapons samples. We anticipate identifying specific audit requirements for this $\$ 215$ million plus program.

o an audit of the capital equipment budget process at the Savannah River site to determine if the budget process ensures that capital equipment is minimized and funds are spent in accordance with Departmental and Congressional guidelines.

o an audit of the inventory management system at the Nevada Test Site to determine if inventories are being controlled and managed efficiently, economically, and in accordance with Federal and Departmental property management regulations. 


\section{NUCLEAR WASTE DISPOSAL}

\section{BACKGROUND}

Nuclear waste Disposal includes all activities directed toward the ultimate disposal of spent nuclear fuel and high-level radioactive waste, including a small research and development program. The FY 1992 Department budget request for Nuclear Waste Disposal is $\$ 305.8$ million to fund Civilian Radioactive waste Research and Development and Nuclear Waste Fund programs. However, the Department's FY 1992 budget also includes funds in the appropriations for Energy Research R\&D, Uranium Enrichment, and Atomic Energy Defense Activities, that impact on waste disposal.

The Civilian Radioactive Waste Research and Development program is comprised of generic research and cooperative agreement activities that are consistent with the Nuclear waste Policy Act of 1982 , as amended. Funding of $\$ 0.7$ million is requested for FY 1992 to provide for the continuation of the remaining cooperative agreement for reactor storage of spent nuclear fuel, the completion and phaseout of remaining generic research on spent fuel storage, and annual reporting requirements.

Established by the Nuclear Waste Policy Act of 1982, as amended, the Nuclear Waste Fund program's goal is to dispose of spent nuclear fuel and high-level radioactive waste from commercial and defense activities in a permanent geologic repository. The Nuclear Waste Policy Amendment Act of 1987 provided a major refocusing of the nuclear waste program, including the designation of Yucca Mountain, Nevada, for detailed characterization to evaluate site suitability for a geologic repository.

In a November 1989 report to Congress, the Department pledged its best efforts toward meeting both near-term and long-term milestones consistent with its goals of safety and technical excellence. To achieve such goals, the secretary announced the initiation of a three-point plan. The plan centered on;

- restructuring the Office of Civilian Radioactive Waste Management (OCRWM);

- initiatives to gain access to the Yucca Mountain site to initiate new scientific investigations needed to evaluate the site's suitability for a repository; and

- an initiative for establishing an integrated Monitored Retrievable storage (MRS) facility with a target for spent fuel acceptance in 1998. 
The FY 1992 Nuclear Waste Fund budget request of $\$ 305.1$ million provides for continuation of the redirected program. The repository request of $\$ 172.2$ million includes funds for site characterization at Yucca Mountain, including limited new surface-based testing activities. For the MRS program, $\$ 32.2$ million is requested to fund siting and preliminary design activities. The transportation/systems integration/engineering development request of $\$ 38.9 \mathrm{milli}$ ion provides for the continued development of from-reactor casks which will be used in the waste management system and for the integration of the overall system. The $\$ 61.8 \mathrm{million}$ program management request funds personnel, contractual support services and technical support for the overall program.

\section{LEVEL OF EFFORT}

During FY 1991, several reports were issued in the Nuclear Waste Disposal area, including:

- Audit of Property and Equipment at Battelle, Columbus, Ohio - A Contractor to the Office of Civilian Radioactive Waste Management (CR-B-91-01, February 13, 1991). The purpose of the audit was to determine if Battelle's property management procedures were in compliance with Department and Federal policies and regulations. Although contractois may purchase property and equipment with contract funds, the property belongs to the U. S. Government. The contractor is responsible for maintaining sufficient internal controls to safeguard and minimize loss of the Government-owned property in their custody. The review disclosed that internal control weaknesses in Battelle's property management system contributed to the loss of equipment in their custody. Battelle officials stated that they are in the planning phase of revising their property management system.

- Audit of Transuranic Waste Processing Facilities Supporting the waste Isolation Pilot Project (WR-L-91-19, June 13,1991 ) where we assessed the Department's management approach to acquiring planned transuranic (TRU) waste processing facilities at several locations. Because the Department has taken or plans to take several initiatives to develop an integrated approach to the waste disposal problem, we made no recommendations in our report. However, we have reservations concerning the Department's ability to design and construct planned TRU waste processing facilities in an integrated manner, primarily because the facilities we examined had been designed on a site-by-site basis. 
During FY 1992, the Office of Audits plans to spend almost nine staff years on audits of Nuclear Waste Lisposal activities. Audits currently in process that will be carried over to FY 1992 include:

- a multi-region audit, "OCRWM Plan for High-level Waste Repository" intended to determine if current expenditures from the Nuclear waste Fund are meeting mission objectives.

- a review to determine whether DOE operating contractors are packaging low-level waste for shipment to disposal sites in the most efficient and cost effective manner.

- a review to determine if the use of commercial disposal sites for the burial of DOE's low-level waste would be feasible and cost effective.

Several new audits are currently planned to start in FY 1992 , including:

- an audit of property designed to determine if adequate controls have been established for the acquisition, use, and disposal of property acquired for the Yucca Mountain Project.

- a review to determine if the west Valley Demonstration Project for nuclear waste management is prudently achieving the results intended by the authorizing legislation. Thru March 1991, about $\$ 500 \mathrm{million}$ had been expended on the project, with approximately $\$ 110$ million in expenditures anticipated in FY 1992.

- a review to determine if the Department should continue the development of canisters for disposing of waste since the NRC has not established canister specifications. Canister development and production costs are estimated to exceed $\$ 50$ million.

- a follow-up review of OCRWM transportation planning to determine if the OCRWM transportation program has progressed on schedule with cask development.

- a financial review of the OCRWM maintenance and operations contractor to assess the reliability of accounting controls, transactions, account balances, and financial reports prepared by TRW Environmental Safety Systems, Inc. 


\section{SAFEGUARDS AND SECURITY}

\section{BACKGROUND}

The Nuclear Safeguards and Security Program is responsible for the development of measures for the protection of nuclear weapons, nuclear materials, facilities, and classified information against theft, sabotage, espionage and terrorist activity. The emphasis of DOE's Safeguards and security activities has shifted to protection against the insider threat.

This program is essential to national security and has attracted a considerable amount of Congressional and public attention. Substantial audit work has been done in this area, but because of its sensitivity and high visibility, the safeguards and security program warrants continued audit attention in the areas of physical and personnel security.

Major objectives for safeguards and security continue to include:

o increase physical security measures designed to protect against internal threat;

o improve classified document/material control;

- continue emphasis on technology upgrades in the material control and accounting area;

o increase emphasis on computer security enhancement activities; and

o strengthen the personnel security/clearance program.

To establish more stringent physical security, DOE plans to design and build state-of-the-art safeguards and security technology systems into its facilities. These improvements will require $\$ 1.1$ billion in capital investment and $\$ 8.6$ billion in operating funds through FY 2010.

As a result of the costs to be incurred and the limited oversight provided by the current organizational structure, concern has risen over the justification for the large expenditures in this area. Also, during recent years, a perception has grown both in the Congress and the media that DOE was increasing security requirements and limiting access with the intent, or at least the result, of hiding environmental and safety problems.

Although the Department is spending billions on safeguards and security measures to protect against outsiders, funding and staffing limitations continue to constrain the implementation of 
controls over clearances for insiders. DOE requires most of its Federal and contractor employees to undergo personnel security investigations and obtain security clearances. These clearances are designed to ensure that those individuals with access to sensitive information or materials are trustworthy.

A review at DOE headquarters found that the average time for processing a security clearance was about ten months, with many employees waiting over a year for their clearances. Further, only about a third of that time was used to conduct the investigation. The balance of the processing time was used in submitting the application for investigation and in making the access determination once the investigation was completed. Processing delays may make it difficult for the Department to gear up to meet urgent production requirements. Additionally, DOE contractors are reluctant to adjust their workforce when the workload decreases because of the time required to obtain clearances for replacement employees.

The clearance workload is larger than warranted for several reasons:

- many employees have been granted clearances at higher levels than required for their jobs;

o many employees work in jobs which do not require clearance;

- procedures to document the need for clearances are not fully effective;

o once the clearance is granted, there are no procedures to review an employee's clearance after transfers which involve a change of duties;

- contractors have not been obtaining important preemployment information on job applicants before they were hired and their names submitted for clearance. Such preliminary information helps to identify job applicants who may be ineligible for a clearance.

In addition to the "first time" investigation requirements, the Department has a large backlog of cases which require reinvestigation as part of the periodic updating of clearances.

other key concerns that Congress and the Department have in the area of Safeguards and Security include:

- Computer security controls - DOE is one of the largest computer users in the Federal Government, with large volumes of unclassified research data being shared by DOE laboratories, via network connections. These systems may be vulnerable to computer viruses and hackers. 
- Training - The Department is concerned about continuing management, procedural and operator training problems in the safety area.

- Security forces -- Some concerns have been raised about law enforcement jurisdiction and the authority of security forces at DOE facilities. Also, there is concern that some security guards may not have security clearances.

\section{LEVEL OF EFFORT}

Although two and a half staff years of effort were planned for the Safeguards \& Security area in FY 1991, almort four staff years had been spent in the first 10 months of the fiscal year. Audit reports completed in this area during the fiscal year include:

- Overtime and Staff Management at Martin Marietta Energy Systems, Inc. Y-12 Plant - Security Patrol Department (ER-B-91-01, November 2, 1990) where we found that Energy Systems' management of overtime and staff at the Y-12 plant was not adequate or in accordance with applicable guidance provided by the U.S. General Accounting office, DOE, the DOE/Energy Systems contract, the Energy Systems/union labor agreement, and Energy Systems' policies and procedures. As a result, Energy systems incurred $\$ 624,000$ in unallowable costs and could save another $\$ 1.8$ million annually in future years through improved efficiency.

- EG\&G Mound Plant Protective Force Administrative and Operational Controls (ER-B-91-04, November 15, 1990) where our objective was to assure that operational and administrative security requirements designed to protect DOE's security interests at the Mound Plant had been implemented by the Mound plant Protective Force. We determined that:

- the Mound plant did not have adequate policies and procedures to preclude material weaknesses in the management of hourly employees time and attendance records.

- controls had not been properly implemented to ensure proper supervision of escorts, and accountability of weapons and keys.

- required routine physical fitness training was not properly supervised or adequately documented, and first-line supervisors did not complete mandatory annual training required by DOE orders. 
- Richland Operations Office Oversight of Management \& operating Contractor Personnel security clearances, Richland, Washington (WR-B-91-1, November 30, 1990) where we evaluated Richland's security clearance policies and timeliness. We found that as of March 1989, Richland had almost 10,000 active " $Q$ " clearances and over 2,800 active "L" clearances. This number of "high level" clearances seems excessive since Richland's primary special Nuclear Material facility had closed and their mission had shifted toward waste management. Richland had not reviewed in-depth the contractor's implementation of DOE and Richland orders which might permit a reduction of some of the security clearance levels. Security reinvestigation costs for maintaining " $Q$ " clearances over the next five years (projected at $\$ 13$ million) could be substantially reduced.

For FY 1992, the office of Audits plans to spend about seven and one half staff years of effort in the area of safeguards and security. One on-going audit of clearance processing and timeliness in the Department will be carried over from FY 1991. Ten new audits are scheduled to start during the year, including:

- reviewing the acquisition of physical security devices to determine if DOE's policies and procedures for justifying expenditures to improve safeguards and security are evenly applied at all locations and assure that security is adequately provided without wasting funds.

- a review of firearms and munitions accountability and inventory control at Albuquerque to determine compliance with laws and regulations, and causes of uneconomical or inefficient practices.

o determining whether controls over the access to classified computer information at the Y-12 Plant are adequate to provide the required protection.

o a review to determine whether computer systems in Albuquerque that are linked to communication networks are secure and have controls to detect and report intrusions or breach of security. 


\section{PROCUREMENT AND GRANTS MANAGEMENT}

\section{BACKGROUND}

Procurement and grant activities affect every program and activity in the Department of Energy. However, unlike most other Federal agencies, DOE does not spend the majority of its procurement dollars on goods and services for its own use. DOE spends its procurement dollars more as a catalyst for technology development, supporting basic and applied research in a wide range of energy related technology areas, including nuclear energy, nuclear waste management, fossil energy, conservation, renewable energy, and nuclear weapons development. DOE procurement activities also support national security in the production and testing of nuclear weapons and the management of the Strategic Petroleum Reserve and the Naval Petroleum and Oil Shale Reserves.

DOE is one of the most active procuring agents in the Federal Government. A substantial portion of this procurement activity is carried out at locations and facilities owned by the DOE, but operated for DOE by its management and operating (M\&O) contractors.

DOE also makes financial assistance awards to state and local governments, colleges, universities, and private sector firms. These financial assistance awards are made for a variety of purposes, including:

o weatherization of the residences of low income citizens;

o promotion of energy conservation by state and local governments, schools, and hospitals; and

o the encouragement of new and emerging energy techniques.

Funds used for these programs come from Congressional appropriations and payments collected from the petroleum industry in settlements for violations of DOE's oil price and allocation controls which were in effect from 1973 to 1981 .

\section{LEVEL OF EFFORT}

During the first 10 months of FY 1991, the Office of Audits spent slightly more than 10 staff years of effort auditing the Procurement and Grants Management area. Reports issued included the following: 
- Procurement Initiated by Transportation Safeguards Division (WR-L-91-14, December 17, 1990). The purpose of the audit was to determine whether Transportation Safeguards Division's procurement practices complied with applicable laws and regulations. Department regulations required the purchase of goods and services for Government employees use where the task is to do work for the Transportation Safeguards Division, but not primarily or solely to procure goods and services for use by Government: employees. Contrary to these policies, Transportation Safeguards Division obtained items for Government employees use through two M\&O contractors. In one instance, this practice led to an uneconomical procurement.

- Followup Review of Major System Acquisitions and Major Projects (DOE/IG-0292, November 1990). In 1985, we conducted an audit of DOE's procedures and practices for managing and controlling its major acquisition program, and found deficiencies in documentation and reporting required by DOE's Project Management System (system).

The current audit disclosed that the Departmental elements responsible for operating and managing major acquisitions still were not in full compliance with documentation and reporting requirements. As a result, the Headquarters review, evaluation and oversight of over $\$ 35$ billion in major acquisitions lacked critically important documentation regarding projects in process. The absence of these documents and the data they are intended to provide increases the possibility of cost overruns and schedule delays. The reviewers were informed that the Departmental elements were not responsive to the requirements of the System because they were not convinced of the benefits of such an orderly process. Management is in the process of taking corrective actions based on our recommendations.

- Review of Headquarters Use of Cost-Reimbursement Contracts (CR-BC-91-01, Apri1 9, 1991). The purpose of this audit was to determine if cost-reimbursement contracts used to procure support services for DOE Headquarters were properly justified in the selection process and if, in fact, they were the appropriate contract type to use in acquiring the specific services required. When costreimbursement contracts are used, a Determination and Findings ( $D \& F$ ) must be prepared to clearly and convincingly justify the determination made. Our review of 23 contracts at DOE Headquarters indicated that none of the D\&Fs contained sufficient information to support the decision to use cost-reimbursement contracts. At least 14 
of the contracts had definitive or recurring requirements making them candidates for fixed-priced contracting. Management partially concurred in our recommendations.

- Cost of Environmental Survey Testing (I.DE/IG-0295, August 1991) where we found that DOE's costs for environmental tests performed by its own laboratories were significantly higher than if DOE had contracted for this work through commercial laboratories, in part, because it did not have an acquisition strategy and did not use competitive procurement for obtaining testing services. Also, at one of the four laboratories included in our review, sufficient detailed cost information could not be obtained to allo: a valid comparison with the costs of testing performen by commercial laboratories. Potential savings could amount to at least $\$ 13.6$ million annually. Management generally agreed with our recommendations.

- Audit of the Cost Effectiveness of Contracting for Headquartcrs Support Services (DOE/IG-0297, August 1991) where we found that costs to perform work in-house were 40 percent less than contractor costs, contracted activities were nevertheless continued because DOE policy did not require a cost comparison analysis as part of the program office request for support services. Potential savings could amount to about $\$ 16.3$ million.

We plan to devote over 16 staff years to Procurement and Grant Management activities during Fiscal Year 1992. Several audits will be carried-in from FY 1991 including:

o a review of Argonne National Laboratory's use of Government supply sources.

o use of the Federal supply system for procurement of recurring items at the Savannah River Site.

- a review of Uranium Mill Tailings Remedial Action (UMTRA) prime contractor procurement.

- a review of the purchase and use of heavy equipment at the Hanford Site in Richland, Washington.

New audits scheduled to begin in FY 1992 include:

o a review of the implementation and cost effectiveness of the Accountability and Award Fee Rule at three management aid cperating contractors at Rocky flats. This rule transfers liability for certain "avoidable" costs from DOE to the contractor.

- a reviein of procurement practices at EG\&G Mound to determine if procurement practices comply with the Federal 
Acquisition Regulations and contractual requirements resulting in the lowest possible prices. Most of EG\&G's procurement dollars are awarded on a noncompetitive, fixed-price basis.

- a review of procurement practices used by DOE Field Office, Nevada contractors. 


\section{EXPANSION OF THE MISSION OF THE LABORATORIES}

\section{BACKGROUND}

DOE'S national laboratories are federally owned facilities operated for the Department by universities, university consortia, or industrial contractors. The contractor operators provide the scientific, technical, and support staff to conduct the work under the general guidance of the Department's program managers. Contract oversight and appraisal of laboratory performance are conducted by the Field offices of the Department. The detailed, day-to-day management of each laboratory is provided by the contractor commanding the best talent from the private sector and operating with considerable flexibility.

The Department owns eleven national laboratories located around the United States. The laboratories and their locations are:

\section{Facility}

Argonne National Laboratory Brookhaven National Laboratory

Fermi National Accelerator Laboratory

Idaho National Engineering Laboratory

Lawrence Berkeley Laboratory

Lawrence Livermore National Laboratory

Los Alamos National Laboratory

National Renewable Energy Laboratory

Oak Ridge National Laboratory

Pacific Northwest Laboratory

Sandia National Laboratory

\section{Location}

Argonne, IL
Upton, NY
Batavia, IL
Idaho Falls, ID
Berkeley, CA
Livermore, CA
Los Alamos, NM
Golden, CO
Oak Ridge, TN
Richland, WA
Albuquerque, NM

The work of the Department's laboratories is focused on basic research and applied research and development problems that require capital-intensive facilities, long-term sustained efforts, or multi-disciplinary team efforts. Most of the large, unique facilities within the system are "designated user facilities" and are made available to researchers from universities and industry, for their own research or for collaborative efforts. Laboratories also further the education of scientists and engineers by offering special training and research opportunities in the many disciplines they represent.

General management oversight of each of the national laboratories is assigned to the secretarial officer with the major share of programmatic activities carried out at the laboratory. Four of the multi-program laboratories are assigned to the Assistant Secretary for Defense Programs, and seven are assigned to the Director of the office of Energy Research. The Director of the office of Energy Research is also responsible for a number of 
Department-wide laboratory management activities, including the institutional planning process, the Laboratory Directed Research Program, the laboratory appraisal process, the Multi-program Energy Laboratory-Facilities support Program, and the Research and Development Laboratory Technology Transfer Program.

The institutional planning process focuses on the mission, well-being, and future development of the laboratories, and provides a mechanism for dealing with problems and issues. A 15 year strategic view is a major part of the institutional planning process.

The Laboratory Directed Research and Development Program provides funds, to be used at the laboratory director's discretion, for early exploration of new scientific and technological concepts arising in the course of work. The Laboratory Directed Research and Development Program has yielded substantive benefits in establishing new directions in scientific programs, revitalizing the innovativeness of the laboratory personnel, and opening new areas of scientific investigation.

The laboratory appraisal process considers program performance and general management, as well as performance in functional areas of administration, such as health, safety, environmental protection, property management, industrial relations, legal serces, and public relations. The appraisal process strengthens the position of the field office manager with respect to the operating contractor's activities and promotes greater flexibility in contractor operations.

The Multi-program Energy Laboratory-Facilities Support Program provides funds for rehabilitation, renovation, and replacement of general-purpose facilities at the five office of Research multi-program laboratories. These "make whole" functions recognize that because of continuous use, aging, and absolescence, the facilities tend to deteriorate to a point where they are no longer appropriate for their intended functions, economically justifiable to maintain, or adequate to meet security, environmental safety, and health requirements.

The Research and Development Laboratory Technology Transfer Program involves the transfer of technology developed at the Department's laboratories to the public and private sectors. Throughout the 1980 's, the Department's technology transfer program was minimal. However, with the passage of the National Competitiveness Technology Transfer Act of 1989, the Department's technology transfer activities began to increase significantly. This Act gave the laboratories authority to enter into Cooperative Research and Development Agreements with private industry. These joint research agreements allow each party to contribute facilities, personnel and equipment. Private industry may also contribute cash, but the laboratories cannot. 
Historically, technology transfer has been funded by the Department's laboratories solely through overhead charges to all programs conducting work at those sites. Beginning with the FY 1993 budget; however, it appears that all technology transfer activities will be included in the Department's budget request. This change will be more conducive to internal Departmental control and $\mathrm{OMB}$ and Congressional review.

\section{LEVEL OF EFFORT}

The office has maintained a presence at many of the National Laboratories over the past several years. However, resources have not generally been available to perform the number of audits that funding levels of these facilities requires. However, we have conducted annual financial audits at the facilities to ensure the reasonableness of expenditures.

During FY 1991 we spent about two staff years auditing the activities of the laboratories. The following two audit reports were issued during the year:

- Martin Marietta Energy Systems, Inc., Subcontracting in the Work-Formothers Program for Data Systems Research and Development Projects (ER-B-91-07, December 21, 1991) where our objective was to determine if work-for-others subcontracting was being done in accordance with DOE approved procurement practices, if these procurements were being properly administered, and whether other agencies were "dumping" year-end funds in the program. In general, we found little problem in this area. We did, however, find indications that Defense Department agencies were "dumping" year-end funds into the program, but because DOE does not control such inter-Departmental spending, no recommendations were made in this area. The office of Audits and the Department of Defense Office of Inspector General are currently conducting a joint audit of reimbursable work being done by Martin Marietta Energy systems and subcontractors.

- Fabrication Department at Oak Ridge National Laboratory, Martin Marietta Systems (ER-BC-91-03, December 24, 1990) where we found that policies and procedures provided adequate controls over Government-owned assets. We did find, however, that the process used by Oak Ridge National Laboratory for deciding to perform fabrication work in-house compared to procurement from outside sources was not appropriate since an adequate make-or-buy program had not been developed for determining whether fabrication or procurement was in the Government's best interest.

We plan to expand our coverage of the National Laboratories in Fiscal Year 1992. At the present time, we plan to spend about 
seven staff years auditing this area. Work planned includes the continuation of ongoing reviews of cooperative research and development agreements administered by the laboratories, and a review of the technology transfer program at the Los Alamos and Sandia National Laboratories.

New audits scheduled for FY 1992 include:

- reviews of technology transfer programs at the Argonne National Laboratory and Martin Marietta Energy Systems to determine whether practices and procedures regarding technology transfer comply with DOE policies, and if the programs are accomplishing their objectives.

o a follow-up to our FY $1990 / 1991$ survey of the technology transfer program at Sandia National Laboratory to determine whether Technology Maturation Program expenditures comply with Departmental and Sandia policy and guidance. 


\section{DETERRENTS}

\section{BACKGROUND}

We have characterized as "deterrents" those activities for which there is high inherent vulnerability to waste and abuse. The purpose of these audits is to avoid waste and abuse by identifying problems before they have a significant impact on operations. Examples of activities include:

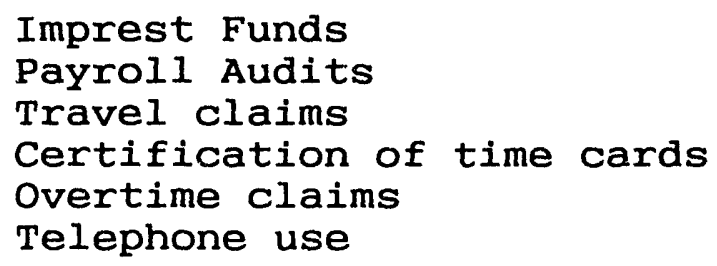

We plan to concentrate on activities most likely to be vulnerable to waste and abuse that can be audited in a short duration. Audits of these activities will, of necessity, cut across program Iines. It is also anticipated that more leads and a better variety of leads to potential investigations will be developed.

Many of these areas have already received some coverage from the Office of Audits and problems have been identified. Further audits as a "deterrent" can help limit the losses that may already be occurring.

\section{LEVEL OF EFFORT}

Through the first 10 months of FY 1991, we spent almost six staff years auditing activities in the area of "deterrents." We also considered "deterrents" while performing audits in other major program areas such as procurement and grants management and financial management.

Examples of "deterrent" audits completed in FY 1991 include audits of imprest funds, travel, telecommunications, and computer access controls. These audits identified problem areas such as weak internal controls over imprest funds. Implementing the recommendations made in these audits will prevent waste and abuse. In addition, "deterrent" audits provided audit leads and investigation referrals.

To illustrate, seven audit reports were issued which disclosed internal control weaknesses in imprest fund management at the following DOE sites: Western Area Power Administration, Oak 
Ridge National Laboratory, Y-12 Plant at Oak Ridge, Brookhaven National Laboratory, Mound Plant in Ohio, Savannah River Site, and Fermi National Accelerator Laboratory.

The most significant internal control weaknesses found in these audits were inadequate segregation of cashier duties, inadequate transaction documentation and procedures, annual audits not being performed, and improper use of imprest funds. The audit reports recommended that some sites follow the internal control procedures which they already have in place, while other sites were advised to develop and implement stricter procedures to preclude opportunities for fraud, waste and abuse.

Another example of a "deterrent" audit completed in FY 1991 is the audit of Telephone costs at Princeton Plasma Physics Laboratory (ER-B-91-17, August 21,1992). This audit reported that personal telephone calls were being charged to the DOE contract because management was not enforcing policies and procedures.

In FY 1992, we plan to spend over six staff years on "dete.rent" audits. This time includes a carry-in FY 1991 audit of policies, procedures, practices, and internal controls for reimbursing employees for travel at the Princeton Plasma Physics Laboratory. New audit starts will include reviews of imprest funds, travel advances, overhead costs, and computer access controls at various Department facilities. In addition, we will look for opportunities to deter waste and abuse while performing audits in the other major program areas. 
NAVAL REACTORS

\section{BACKGROUND}

The naval nuclear propulsion program is carried out jointly by the Department of Energy and the U.S. Navy. Its purpose is to provide the Navy with effective nuclear propulsion plants and to ensure their safe and reliable operation. The program is responsible for all aspects of nuclear propulsion from plant design through operation and eventual disposal. priority is given to ensuring the viability of the existing nuclear powered fleet by applying new technology and improved features to these vessels.

Major components of the program are:

- reactor development work to achieve higher power density reactors with greater endurance and to improve capability and reliability of current reactors;

- plant development aimed at improving performance and longevity of the entire reactor plant operations including development of components, plant arrangement studies, and generic chemistry and materials technology to support existing and advanced plant concepts;

- reactor operation and evaluation activities involving the operation and maintenance of seven land-based prototype nuclear propulsion plants used for testing;

o program direction covering personnel and other costs at the Naval Reactors Office in Washington, D.C., at field offices in Pittsburgh, PA and Schenectady, NY; and at the DOE Field office, Idaho.

o capital equipment and construction; and

o enriched material to meet naval fuel requirements.

During FY 1992, work will continue to improve existing submarine and surface ship reactors and plant components, and to develop advanced reactor concepts and propulsion plants. Major efforts include the Advanced Fleet Reactor, which is bringing together advances in reactor technologies, components, and materials to power the SEAWOLF class attack submarine. The FY 1992 budget request of $\$ 678$ million maintains the Advanced Fleet Reactor effort on schedule, and also continues the 10-year extensive servicing and refueling effort of the seven land-based prototype 
naval reactor plants. In addition, the FY 1992 budget request of $\$ 123$ million for the enriched materials program is required to meet construction and replacement core needs of the U.S. Navy.

The Naval Reactors Program is an integral part of the Department's strategy for meeting national defense needs through and the program's objectives of developing, and providing nuclear propulsion for Navy vessels. The bulk of the program's funding passes through two prime M\&O contractors:

o Westinghouse Electric operates the Bettis Atomic Power Laboratory near Pittsburgh, PA and the Idaho Naval Reactor Facility. Westinghouse reports to the Pittsburgh Naval Reactor Office of DOE.

- General Electric operates the Knolls Atomic Power Laboratory in schenectady, NY and reports to DOE's Schenectady Naval Reactors office.

Since the majority of the program funding passes through these M\&O's, our program audit efforts will focus on the activities of these integrated contractors.

\section{LEVEL OF EFFORT}

Through the first 10 months of FY 1991, the Office of Audits has spent over three staff years auditing the Naval Reactor program. These audits have focused on financial and compliance activities of the two M\&O contractors noted above. A total of nine reports were issued during the first ten months. Reports issued include:

- Procurement Operations at Bettis Atomic Power Laboratory and Idaho Naval reactor Facilities (CR-91-L-30, March 7, 1991) and Procurement Operations at Knolls Atomic Power Laboratory (CR-L-91-34, March 15, 1991).

- Financial Management at Knolls Atomic Power Laboratory (CR-L-9131, March 15, 1991) and Financial Management Functions at Bettis Atomic Power Laboratory (CR-L-91-33, March 15, 1991).

- Transportation and Travel Activity at Pittsburgh Naval Reactors (CR-L-91-32, March 15, 1991).

- Automated Data Processing and Telecommunications Management at Knolls Atomic Power Laboratory (CR-L-91-35, May 7, 1991).

The results of these audits indicate that, in the above areas, the Naval Reactors program had established effective internal control structures. 
In addition, survey efforts were initiated in the enriched materials and materials development areas, an area the naval Reactors program recently gained responsibility for.

For FY 1992 the office of Audits plans to spend about two staff years of effort in the Naval Reactors area. Planned audits will be financial and compliance in nature and concentrate on the areas of Budgeting, Compensation and Benefits. Based on survey results, additional efforts may be pursued in the enriched materials and materials development areas. 


\section{STRATEGIC PETROLEUM RESERVE}

\section{BACKGROUND}

The Strategic Petroleum Reserve (SPR) was created in 1975, and is authorized to store up to 1 billion barrels of crude oil. The SPR's purpose is to diminish U.S. vulnerability to the effects of interruptions in foreign crude oil and petroleum product supplies. The crude oil is stored at six underground oil storage sites located in southern Louisiana and eastern Texas. These facilities are connected to major private sector distribution systems. At present, the SPR can withdraw at a maximum sustained rate of 3.5 million barrels per day for a 90-day period. Boeing Petroleum Services, Inc., a contractor, operates the Reserve for the Department.

Typically, one or more large scale drawdowns of individual sites are made annually, with numerous other oil movements carried out at all sites as part of routine operations. Prior to January 1991, two actual test sales involving purchases of crude oil (1.1 million and 3.9 million barrels) by the private sector had occurred.

In January 1991, following the start of Operation Desert Storm, the Department sold 17.3 million barrels of crude oil from the strategic Petroleum Reserve. The sale was a precautionary move to counter any possible disturbance in oil supplies caused by the outbreak of Middle East hostilities. This "drawdown" was made from four storage facilities along the Gulf coast.

At that time, there was a total of 585 million barrels in the Reserve, representing an investment of nearly $\$ 20$ billion in facilities and oil purchases.

The FY 1992 budget request for the Strategic Petroleum Reserve is $\$ 382$ million, down from the FY 1991 estimate of $\$ 431.7$ million. The budget decrease is primarily in three areas, operations and maintenance, capital improvements, and distribution enhancements. The budget proposes to resume filling the SPR in the last half of FY 1992 at a rate of up to 50 thousand barrels per day. Oil would be acquired by long term lease or other suitable alternative rather than direct purchase. The FY 1992 budget approach to fill with leased, instead of purchased, oil reflects the strategy of assuring a large inventory for use during an energy emergency without large upfront outlays of money.

Options are also being studied for expanding the Reserve from 750 million to 1 billion barrels. 
Level of Effort

During Fy 1991, we spent slightly over one staff year auditing activities of the strategic Petroleum Reserve. For the first three-quarters of the year, audits were done by staff drawn from various OIG offices. However, in June 1991, an Office was established in New Orleans, LA, that will have primary responsibility for audits of the SPR. The office is currently staffed by four auditors and has one vacant auditor position.

During FY 1991, two reports on the Strategic Petroleum Reserve were issued:

- Quality Assurance Program at the Strategic Petroleum Reserve (ER-BC-91-01, December 18, 1990) where we found that SPR's correction of quality assurance program deficiencies found by an external organization was not timely. We found that the number of change orders being experienced by the SPR Project Management office was excessive; that improvements were needed in the inspection process for critical system components; and that construction claims were not reported as contingent liabilities in annual financial statements, leading to incomplete and misleading year-end financial statements. Management concurred with most of our recommendations.

- Long-range Planning for Physical Security requirements at the strategic Petroleum Reserve (ER-LC-91-01, January 2,1991) where our objective was to determine whether the SPR Project Management office, through its operating contractor, Boeing Petroleum Services, Inc., had developed and implemented a physical security program that requires long-range planning to meet security needs. We found that a DOE approved Master Security Agreement plan was in place. Our analysis of selected aspects of this plan raised questions as to whether the DOE guidance under which the plan was developed provided reasonable assurance that security objectives would be obtained in a cost effective manner. No recommendations related to the SPR plan were made in the report.

During FY 1992, we plan to spend about four staff years auditing the Strategic Petroleum Reserve. Three audits will be carried in from FY 1991. They are audits of:

- Crude oil Accountability at the strategic Petroleum Reserve where we will determine if SPR policies, procedures, and practices provide reasonable assurance as to the adequacy and correctness of data and documentation relating to SPR's crude oil receipts, transfers, and sales. 
- Internal Controls over Computer-processed Financial Data at Boeing Petroleum Services to determine if controls are adequate to ensure the reliability, relevance, and completeness of the data.

- The Payroll system at the Strategic Petroleum Reserve to determine the adequacy of Boeing Petroleum Services, Inc. policies, procedures, and controls over the payroll systems. An earlier audit disclosed a problem with the use of passwords in the payroll system that could permit illegal payroll transactions.

We also plan to start three new audits during FY 1992. One audit will focus on determining whether Boeing Petroleum Services, Inc. procurement activities are performed in accordance with the Federal Acquisition and Department of Energy Acquisition Regulations. The other two audits will look at the oil sale process and the drawdown process from the Strategic Petroleum Reserve that occurred in conjunction with Operation Desert Storm in January 1991. 


\section{POWER MARKETING ADMINISTRATIUNS}

\section{BACKGROUND}

The Department of Energy Organization Act of 1977 transferred the five Power Marketing Administrations (PMAs) - Alaska, Bonneville, Southeastern, Southwestern, and Western Area - to DOE while preserving them as separate and distinct entities. Each PMA markets low cost, subsidized hydroelectric power within its own geographic boundaries. Revenues from selling power and transmission services are used to repay annual operations and maintenance costs, repay the capital investment with interest, and assist capital repayment on irrigation features of certain projects. Revenues are also used to pay for certain conservation and wildlife programs.

The five Power Marketing Administrations market the power generated at all federal multiple-purpose water projects except those under the jurisdiction of the Tennessee Valley Authority. To carry out their responsibilities, the PMAs contract for the purchase and sale of power; develop rates; construct and maintain transmission lines, substations, switchyards, and attendant facilities; and conduct appropriate energy conservation programs.

The energy output of these hydroelectric projects accounts for about 45 percent of the Nation's hydroelectric power production, or 6 percent of the Nation's total electric power.

Alaska Power Administration (APA) is responsible for power operation, maintenance, and marketing for two hydroelectric projects in Alaska - the Eklutna Project near Anchorage and the Snettisham Project near Juneau. Purchase agreements have been successfully negotiated by the Department to sell these two hydroelectric facilities. The FY 1992 budget assumes the divestiture will be authorized and implemented by the end of FY 1992 .

Bonneville Power Administration (BPA) provides wholesale electric power service to the Pacifia Northwest, a 300,000 square-mile service area that encompasses oregon, Washington, Idaho, western Montana, and portions of several other states in the Columbia River Drainage basin. BPA markets hydroelectric power from 30 U.S. Army Corps of Engineers and Bureau of Reclamation projects and from certain non-federal hydro, thermal, and nuclear generating plants in the region. BPA provides about 80 percent of the region's electric power transmission capacity.

BPA is self-financed through a revolving fund, operating under the provisions of the Government Corporations control Act, and has authority to borrow funds from the U.S. Ireasury to finance capital additions. In FY 1992 these include increased conser- 
vation investments; higher spending to improve transmission system reliability; an increased emphasis on replacing obsolete and maintenance-intensive transmission and PCB-contaminated equipment; and construction of fish protection and enhancement facilities.

Southeastern Power Administration (Southeastern or SEPA) handles the sale and transmission of Federal hydroelectric power generated at 22 hydroelectric projects in a 10 state area of the southeast. Southeastern sells power at wholesale primarily to publicly and cooperatively-owned electric distribution utilities using wheeling agreements with the region's large private utilities. Southeastern does not own or operate any transmission facilities.

Southwestern Power Administration (Southwestern or SNPA) operates in a six-state area of the southwest, serving as marketing agent for hyāroelectric power produced at 24 Corps of Engineer projects. Power is sold at wholesale primarily to publicly and cooperatively-owned electric cistribution utilities. Southwestern also operates and maintains transmission lines, substations and switching stations.

Western Area Power Administration (WAPA) handles transmission and marketing of Federal hydroelectric power in 15 central and western states. Power is generated from federallyowned power plants operated primarily by the Bureau of Reclamation, Corps of Engineers, and the International Boundary and Water Commission. The Colorado River Basins Power Marketing Fund is WAPA's business-type revolving fund, which is used for routine operation and maintenance and power marketing expenses of three power projects.

In theory, the five PMAs are almost self-supporting. The initial investment by the taxpayers, to build the generating and transmission facilities, is repaid with interest by the PMAs to the Treasury. The PMAs are not fully self-supporting because the repayment terms are often less stringent than market conditions would require. Also, certain payroll related overhead expenses are borne by the Federal Government and are not reimbursed from ratepayer revenues. Repayments to the Treasury are made in different ways, but they all derive from the fact that the revenues of the five PMAs exceed their operating expenses by a wide margin. The following table demonstrates the magnitude of the estimated maximum amounts that the five PMAs could repay to the taxpayers in FY 1991 and FY 1992. 


\begin{tabular}{||c||r|r|r|r|r|r||}
\hline \multicolumn{7}{|c||}{ Estimated Maximum Repayments from PMAs to the Treasury } \\
(in Million \$s)
\end{tabular}

FY 1992 DEPARTMENTAL INITIATIVES

\section{Proposed Changes in Repayment Terms}

The President's budget proposes to make the PMAs cover the government's true costs of providing power by eliminating Treasury financing subsidies and requiring the PMAs to operate in a more business-like manner. Legislation will be introduced to require the PMAs to make scheduled annual payments of unpaid principal on their federal investment, excluding irrigation investment, by adopting a mortgage-type amortization approach. The Federal investment would be repaid with interest rates on unpaid appropriated debt balances accruing at the historic long-term Treasury interest rates in effect at the time each investment was placed in service. Treasury interest rates in effect when investments are placed in service will be applied to all future investments with the exception of construction loans, which would be granted appropriate shorter-term interest rates and subsequently capitalized. In FY 1992, an estimated $\$ 393$ million in additional receipts is expected to be generated by this reform. Over the next five years thesa proposed reforms are expected to produce over $\$ 2.0$ billion in additional receipts to the Treasury.

\section{Regulatory Issues}

The Department's Hydroelectric Systems Program ( $\$ 1.0$ million) is aimed at resolving technical and institutional regulatory impediments to developing additional hydroelectric capacity and relicensing of existing capacity without undesirable environmen- 
tal impacts. Studies and coordinating activities involving interested parties will be conducted in order to define environmental evaluation criteria and methodologies and to determine the effectiveness of environmental mitigation related to such vital concerns as dissolved oxygen, in-stream flow, and fish passage.

\section{Research and Development}

The expansion of the electric power network over the upcoming decade, coupled with the introduction of intermittent and dispersed generation sources, will present a variety of new challenges to maintaining an adequate and reliable supply of electricity. Many of these will be resolved through development of more efficient ways to transmit electric power and deployment of advanced load-leveling battery technology vital to the control and efficiency of the grid as major capacity additions begin to occur in the mid-term. The Department supports research $(\$ 8.1$ million) to improve the capacity, reliability, efficiency and control of these systems. The Department also investigates the potential health effects from exposure to electric and magnetic fields associated with electric transmission and distribution systems.

\section{Sale of the PMAs}

As noted above, purchase agreements have been successfully negotiated for the Department to sell the two hydroelectric projects whose power is marketed by APA. To the extent feasible, this divestiture will be accomplished with no significant power rate increases for ratepayers. Administration activities will be coordinated with Congress and existing power customers, and implementation will not proceed until necessary legislative approvals have been received.

\section{LEVEL OF EFFORT}

During FY 1991, 16 reports dealing with the PMAs were issued. These reports included ten mandatory audits and six performance audits.

Mandatory audits included:

- audits of the FY 1990 Year-End Financial Statements of each of the five PMAs. Two of these audits were performed by CPA firms contracted for by the PMAs with prior approval of the OIG.

o reviews of the FY 1990 FMFIA reports produced by each of the five PMAs. 
The most significant findings resulting from the mandatory audits were disclosed in the Federal Managers' Financial Integrity Act, FY 1990 -- Assurance Memorandum filed by the Bonneville Power Administration (WR-L-91-3, November 17, 1990). Our review of this Assurance Memorandum disclosed that BPA did not report three significant uncorrected internal control deficiencies relating to environmental violations and potential violations of the Federal Acquisition Regulations.

Performance audits included the following:

- Review of Security Clearances at Bonneville Power Administration, Portland, Oregon (WR-B-91-5, January 9, 1991 ) where we determined that Bonneville had requested security clearances for 242 positions when clearances were not needed, and had designated nine positions at a higher clearance level than needed. The excessive number and level of clearances strains the already overloaded personnel clearance activities of the Department, and will lead to unnecessary cost of about $\$ 163,000$ over the next five years. Bonneville concurred in our findings and recommendations, and has initiated corrective actions.

- Puget Sound Area Imprest Funds, Bonneville Power Administration, Portland, Oregon (WR-B-91-7, August 15, 1991). This audit found that Bonneville was not reporting discrepancies in fund balances as required; that employees were being reimbursed for small purchases that should have been ordered from warehouse stock; and that Bonneville did not follow regulations for documenting small purchases, disbursing cash advances, or segregating and securing imprest funds. Of the 1,454 cash disbursements we sampled, 828 or $57 \%$ did not meet requirements for disbursement from imprest funds. Bonneville agreed with our findings and is in the process of correcting the problems.

Other reports issued during FY 1991 relating to the Power Marketing Administrations dealt with:

- Non-Competitive Procurements at Bonneville;

- Quality Assurance Review of the Audits of the FY 1986 and FY 1988 Financial Statements of Bonneville; and

o Western Area Power Administration Imprest Funds.

Two audits were still in process at the end of FY 1991. About one staff-year is scheduled in FY 1992 to complete:

- An audit of Bonneville's Environmental Budgeting, Reporting and Training designed to determine if Bonneville 
had properly budgeted for and reported on its environmental protection programs and to determine if they had provided the required environmental training to employees.

- An audit of Debt Management at the Bonneville Power Administration to determine if Bonneville's financial. reports contained misleading information on debts and expenses, whether payments being made to the Treasury were from approved sources, and if Bonneville properly issued new debt instruments.

About three and a half staff-years of time are scheduled for 17 new audits planned for FY 1992 dealing with the PMAs. Some of the audits scheduled are:

o audits of the FY 1991 Year-End Financial statements of each of the five PMAs;

o audits of the FY 1991 FMFIA reports produced by each of the five PMAs;

o a review of the work-for others program at the Western Area Power Administration where we will determine if the financial administration of reimbursable work at western is in compliance with DOE and Western Orders;

- a survey of the proposed sale of the Alaska Power Administration where we will determine whether the terms of the proposed sale protect the financial interests of the U.S. taxpayers and the long-term power needs of the Alaska ratepayers;

o a review of travel payments at the Bonneville Power Administration;

- a review of substation inventory management by the Bonneville Power Administration;

- a follow-up to an Investigative Report on Bonneville Procurements; and

- a review of Accounts Receivable at the Western Area Power Administration. 


\section{SUPERCONDUCTING SUPER COLLIDER}

\section{BACKGROUND}

Research in high energy physics is directed at understanding the nature of matter and energy, and the basic forces which govern all processes in nature at the most fundamental level. Experimental research in high energy physics most often requires the use of large particle accelerators, colliding beam devices, and large particle detectors.

DOE has determined that a new, more powerful particle accelerator capable of exploring the trillion electron volt mass region is essential to advance understanding of the fundamental nature of matter and energy and to enable the U.S. High Energy Physics program to remain at the research frontier in the mid-1990's and beyond. The Superconducting Super Collider (SSC) is the proposed new particle accelerator which is capable of meeting these needs.

The SSC is a proton-proton collider having the energy of 20 trillion electron volts per beam. It is intended to be the world's most powerful particle accelerator and a major resource for science education. Using approximately 12,000 superconconducting magnets, the SSC is designed to focus and guide protons in counter rotating beams around a 54 mile racetrackshaped tunnel. The magnets will guide the acceleration of the protons to nearly the speed of light so that they can smash together at a force far greater than any collision on earth. The force of impact will be over 20 times as strong as the Department's most advanced existing accelerator at the Fermi National Accelerator Laboratory.

The SSC is a critical part of the Administration's initiative to strengthen the scientific and technological position of the nation. It will be both a symbol of the nation's commitment to scientific leadership in this century and the next, and an instrument by which U.S. leadership can be maintained.

Construction and operation of the SSC represents one of the most ambitious basic research projects ever undertaken by the Federal Government. The SSC will permit physics research which currently cannot be accomplished by any facility either in existence or planned.

Ellis county, Texas has been selected as the site for construction of the SSC. DOE has selected and signed a contract with Universities Research Association, Inc., a consortium of 66 universities and two private companies, to be the management and operating contractor of the facility. 
As recently as December 1989 , total cost of the project was estimated to be $\$ 5.9$ billion with the Federal share amounting to $\$ 4.1$ billion. Currently, the Department has established a cost base line for the project of $\$ 8.2$ billion, with one-third of the overall funding of the project coming from non-Federal sources, including the state of Texas. Completion is targeted for the end of FY 1999 .

\section{Program Funding}

The following table indicates the level of Federal funding for Fiscal Years 1988 through 1992. The large increase in funds requested for FY 1992 are concentrated in capital equipment and particularly construction. Future funding levels are estimated to be about $\$ 750$ million per year.

\section{Authority}

Fiscal Year 1988

Fiscal Year 1989

Fiscal Year 1990

Fiscal Year 1991

Fiscal Year 1992 (requested)
Budget

(in millions)

$\$ 33.0$

97.6

192.7

267.1

533.7

\section{LEVEL OF EFFORT}

Due to the large Federal expenditures involved and the Departments' past history of cost overruns associated with projects of this type and size, an early audit presence was considered necessary. A program of this magnitude warrants a resident audit staff, but there are insufficient resources to assign a permanent staff at this time.

During the first 10 months of FY 1991, about two staff years of audit effort was directed at the Superconducting super Collider Program. In November 1990 a Special Report on the Department of Energy's Superconducting Super Collider Program (DOE/IG-0291) was issued. The report identified six specific issues involving either the need for key decisions concerning the program or for crucial internal controls that were lacking. These areas are:

o project funding,

o the Magnet Development Program,

o DOE management structure and staffing,

- land acquisition requirements,

- financial internal controls, and

o management and operating contract provisions. 
A total of 24 suggested actions relating to the six areas wexe presented in the report for consideration by the secretary and program officials.

For FY 1992, we plan to spend a just under three staff years on audits of the Superconducting Super Collider Program. A followup audit to the special report discussed above to assess management's progress in correcting financial control weaknesses identified in the earlier report is being carried over from FY 1991 .. The audit will also determine whether DOE's management structure and command and control mechanisms assure effective oversight and an adequate DOE role in the SSC's decision making process.

Two new audits are scheduled for FY 1992. One audit will cover the area of financial accounting and certification of costs associated with the program, and the second will review the management of conventional construction activities associated with the program. This audit is designed as a review of all phases of SSC construction, including quality, useability and cost effectiveness of completed work. ES\&H issues concerning the construction, costs currently being incurred, and completion timetables for various construction activities will also be reviewed. 


\section{FINANCIAL MANAGEMENT}

\section{BACKGROUND}

The issue of financial management cuts across all program areas in the Department of Energy. The primary focus in the financial management area is on proper accountability. A number of processes have been developed in the Department to help ensure that proper accountability is achieved. These processes include:

o annual reviews of the Department's internal control system under the Federal Managers' Financial Integrity Act;

- certification of selected Departmental financial statestatements as required by the Chief Financial officers Act; and

o other reviews of the Department's financial management systems.

Much of the audit work done in the area of financial management is required by law. One of the largest audit undertakings in this area is the annual review required by the Federal Managers' Financial Integrity Act. Under this Act, the Office of Inspector General examines the assurance letters prepared by all Departmental elements, as well as the letter prepared by the Secretary, and expresses its views on the status of internal controls and material weaknesses in the Department. During FY 1992, we will spend over three staff years in this area.

Certification of selected Departmental financial statements is required by the Chief Financial Officers Act of 1990. At the current time, this Act requires the OIG to conduct or oversee financial statement audits of DOE trust and commercial operations. For FY 1991, audits were underway at 10 entities. These audits are being conducted in two phases. Phase I focuses on an auditability survey and obtaining an understanding of the entities internal control structure. Phase II will test the transactions based on results of phase $I$ work and result in an audit opinion and reports on internal controls and compliance with laws. This work must be completed by June 1992. Statements to be audited include those of the five Power Marketing Administrations, the two Naval Petroleum Reserves, the Uranium Enrichment Program, the Federal Energy Regulatory Commission, and the Low-Level Radioactive Waste Fund. These audits will be performed by certified public accounting firms for the office of Inspector General.

We are also required by law to annually audit and report to Congress on DOE's use of "Superfund" monies. These are funds 
collected from utilities generating nuclear waste. The audit is designed to determine if obligations, disbursements, and reimbursements are reasonable, allowable, and adequately supported.

In addition to these mandates, the Office of Inspector General is required by DOE Order to periodically examine the reliability of the internal controls used by the Department's integrated contractors and affected field elements to assure that only reasonable and allowable costs are claimed and reimbursed.

\section{LEVEL OF EFFORT}

The area of financial management has received intensive coverage in recent years, and mandated requirements, along with good auditing practices, necessitate that a strong audit presence continue.

Through the first 10 month of FY 1991, we spent almost 20 staff years reviewing the Department's financial management functions. Over 120 reports were issued during that time relating to the financial status of various DOE operations or to the required reporting under the FMFIA. Other than audits required by the FMFIA, we reviewed vouchers submitted by the Department's integrated contractors, conducted an audit of DOE's use of Superfund monies, performed reviews of selected reimbursable work programs and conducted an examination of the accounting for construction projects at one of the Department's larger sites.

In addition to the above, some more narrowly scoped audits were conducted during the year. One audit report issued during the year was on Department Management of the Ross Aviation, Inc. Contract Aircraft Major Spare Parts Inventory, Albuquerque, New Mexico (WR-B-91-6, July 26, 1991) where we found internal control deficiencies that led to excessive spare parts valued at approximately $\$ 447,000$, including interest carrying costs associated with the parts. The DOE Field Office, Albuquerque agreed to take the corrective actions recommended in our report.

For FY 1992, approximately 43 staff years of audit effort are scheduled for reviews in the financial management area. A number of audits will be carried over from FY 1991. Some of these include:

- an audit of overhead rates at the Oak Ridge National Laboratory where we will determine the propriety of the composition and distribution of the ORNL General and Administrative / General Plant Services rate.

- a review of the debt collection process at the western Area Power Administration. 
- a review of overtime charges at the Naval Petroleum Reserve No. 1 to determine if the contractor's internal controls assure that only overtime needed to meet cperational requirements is approved. We are also evaluating the Department's administration of the contractors overtime management.

- a review of internal controls over computer processed financial data at the Nevada Test Site. The primary contractor at the test site has an annual budget of about $\$ 200$ million and produces large amounts of computer processed information, including budgets, work orders, payroll, inventory, and general ledger accounting. DOE and contractor managers rely heavily on this computer generated information. Our objective is to determine if the contractors internal controls over the computer processed financial data are adequate to ensure reliability of the data.

- a review of the composition and reasonableness of costs included in the indirect cost structure at the Los Alamos National Laboratory.

In FY 1992, we will continue to review the year-end assurance memoranda prepared by Department managers on the adequacy of internal control systems within their programs. We will continue to review vouchers submitted by the integrated contractors and examining the controls over reimbursable work and construction projects. The office of Inspector General will also issue certified opinions on 10 Departmental financial statements in FY 1392, and begin preparations for the addition of an eleventh statement to be audited in FY 1993. Other new audits to begin in FY 1992 include:

- two audits at DOE integrated contractors to evaluate indirect cost structures and determine if their systems of accounting for indirect costs precludes the allocation of unallowable costs to government contracts.

o an audit at the DOE Field Office, Albuquerque to determine whether there are reasonable assurances that depreciation and added factor costs are waived only when work done in DOE facilities for non-Federal "sponsors" benefits the Department.

o an audit of cost allocations between Stanford University and the Stanford Linear Accelerator to determine if cost sharing arrangements between them result in reasonable allocations of costs. Based on recently publicized evidence of overcharges made by the university to the government, internal controls appear to be weak. 


\section{DOE INSPECTOR GENERAL OFFICE OF AUDITS FISCAL YEAR 1992 ANNUAL WORK PLAN HEADQUARTERS}

AUDIT OVERSIGHT

PLANNING \& POLICY

BUDGET ACTIVITIES

TRAINING \& PERSONNEL COORDINATION

MISC. ASSIST \& SUPPORT ACTIVITIES

1100

MANAGEMENT \& ADMINISTRATION

1175

INDIRECT TIME

2600

TOTAL PLANNED DAYS

7540

INDIRECT TIME INCLUDES:

LEAVE AND HOLIDAYS

TRAINING

SECRETARIAL SUPPORT

OTHER AUDIT SUPPORT ACTIVITIES 


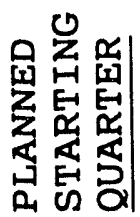

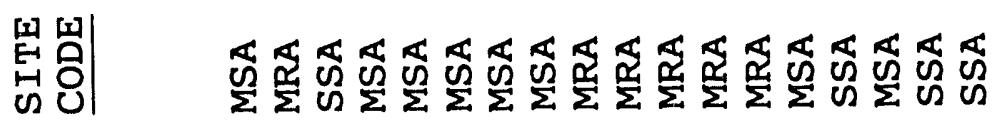

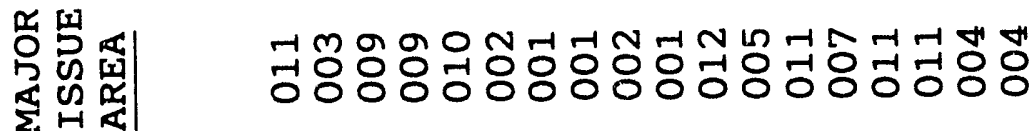

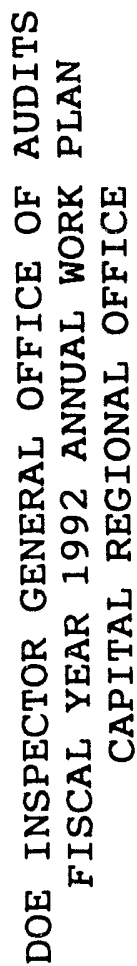

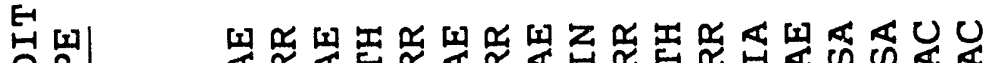

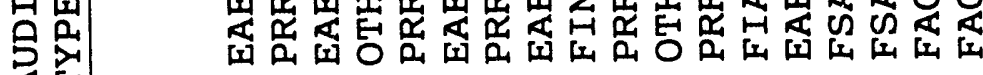

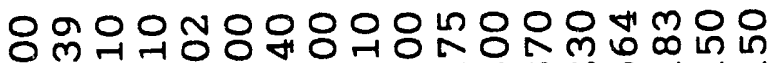

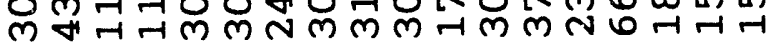

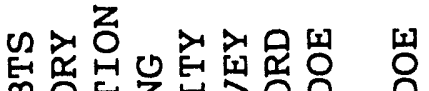

mO

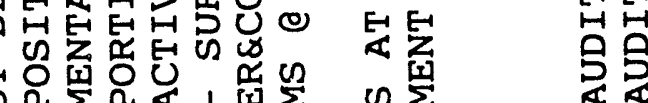

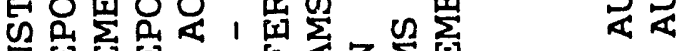

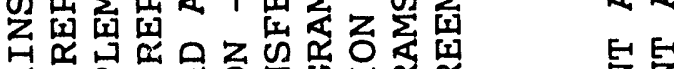

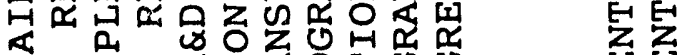

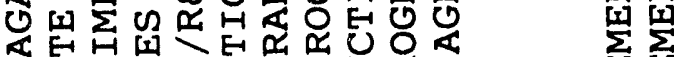

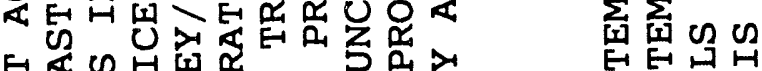

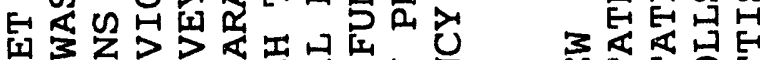

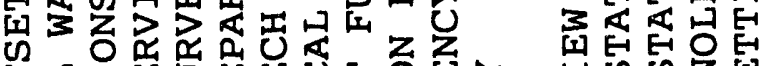

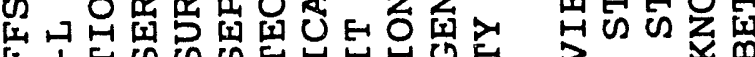

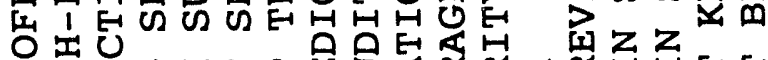

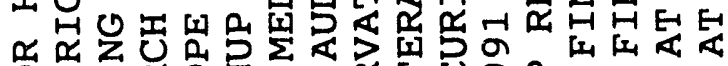

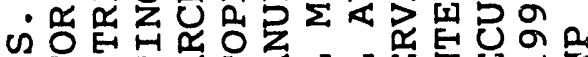

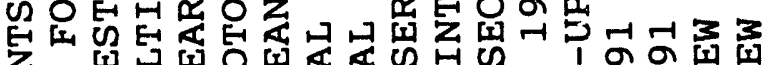

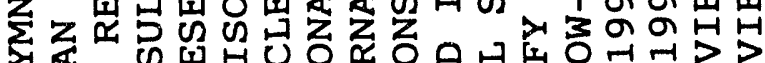

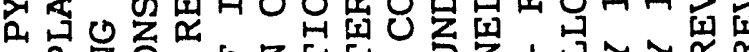

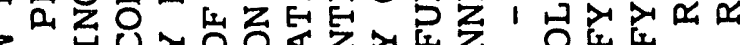

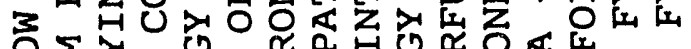

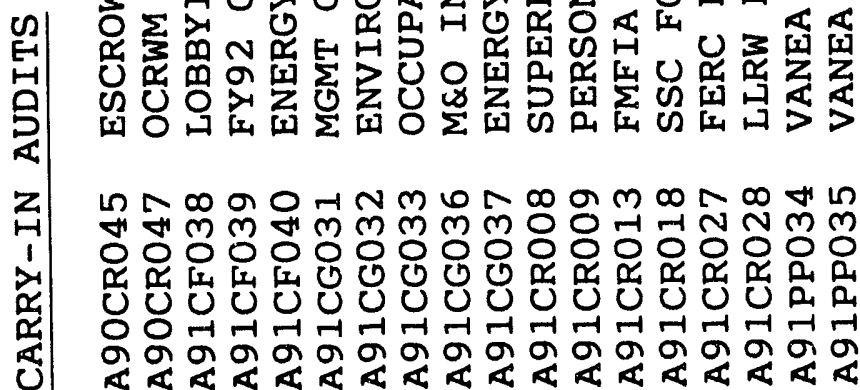




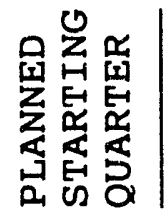

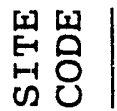

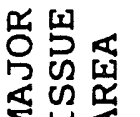

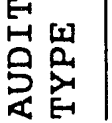

告嵒

质采界

-

[1 3 [4

$\mapsto \mapsto 0$

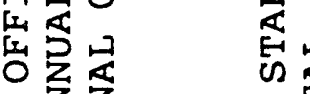

]全各

$\$ \sim$

जी का

z o

(I)

$\propto \stackrel{1}{\alpha}$

$\alpha$ \& $E$

E- 시 D

$U_{0} \rightarrow U$

回起

00

庄

ㅁํำ

0

D.

幽

(1)

ए

E-1

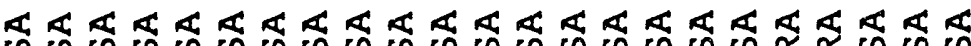

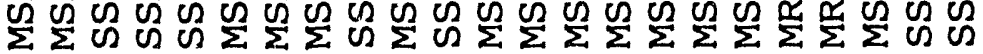

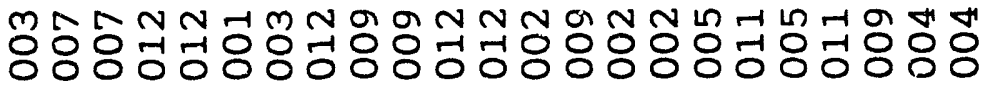

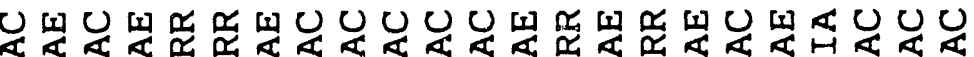

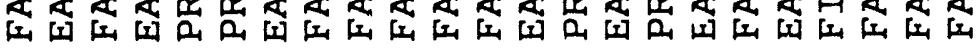

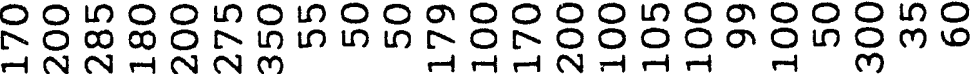

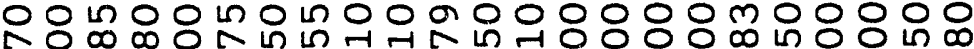

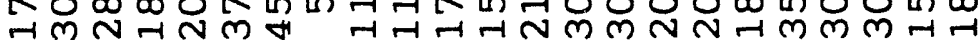

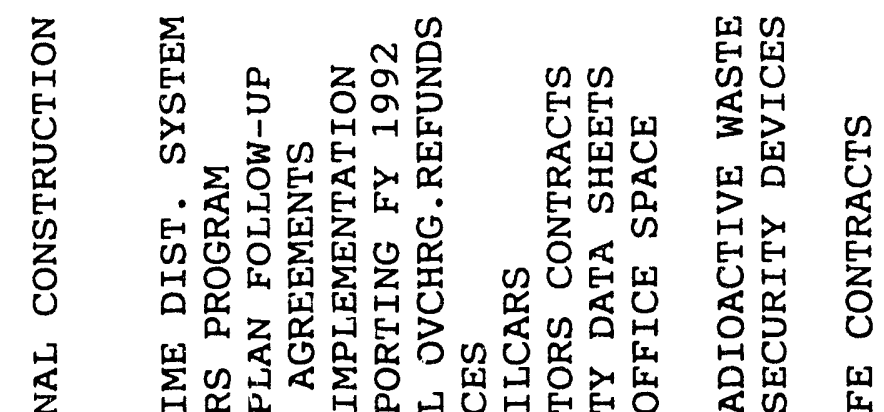

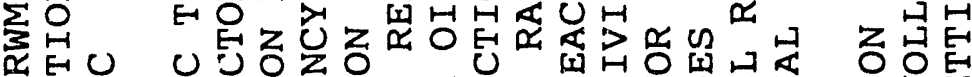

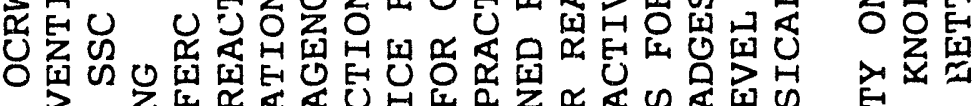

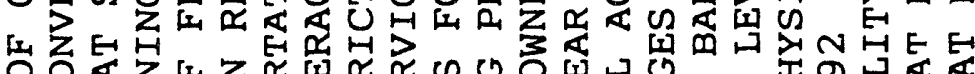

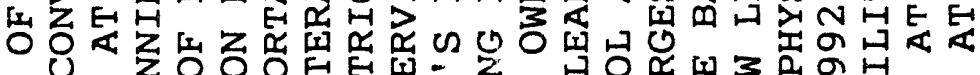

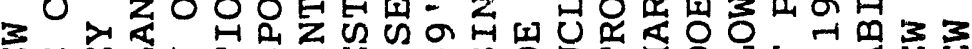

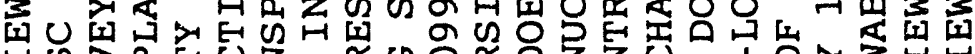

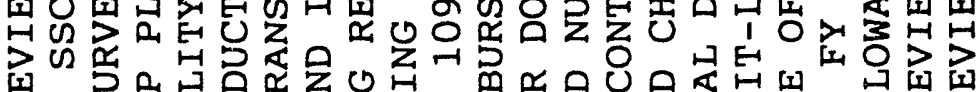

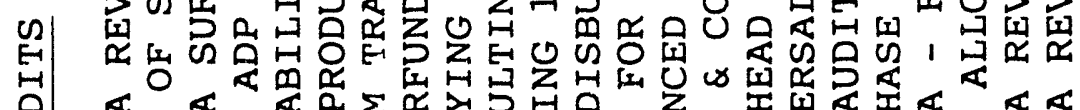

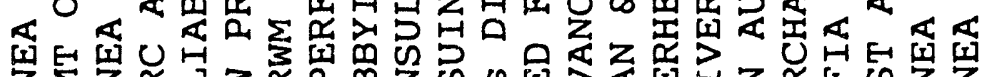

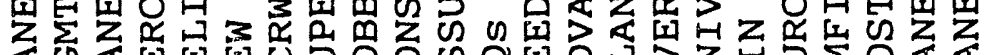

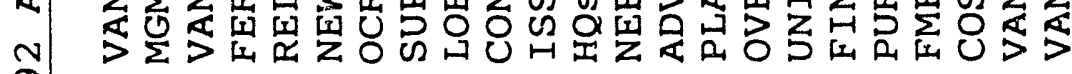

-1NM

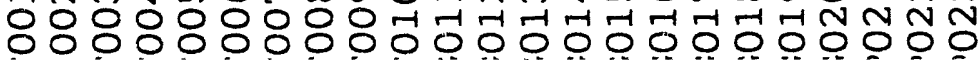

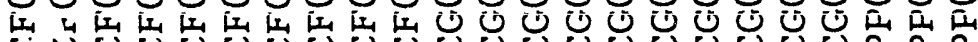

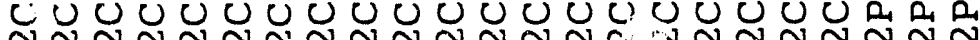

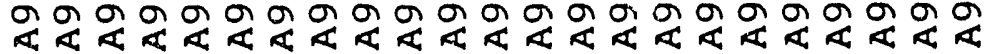




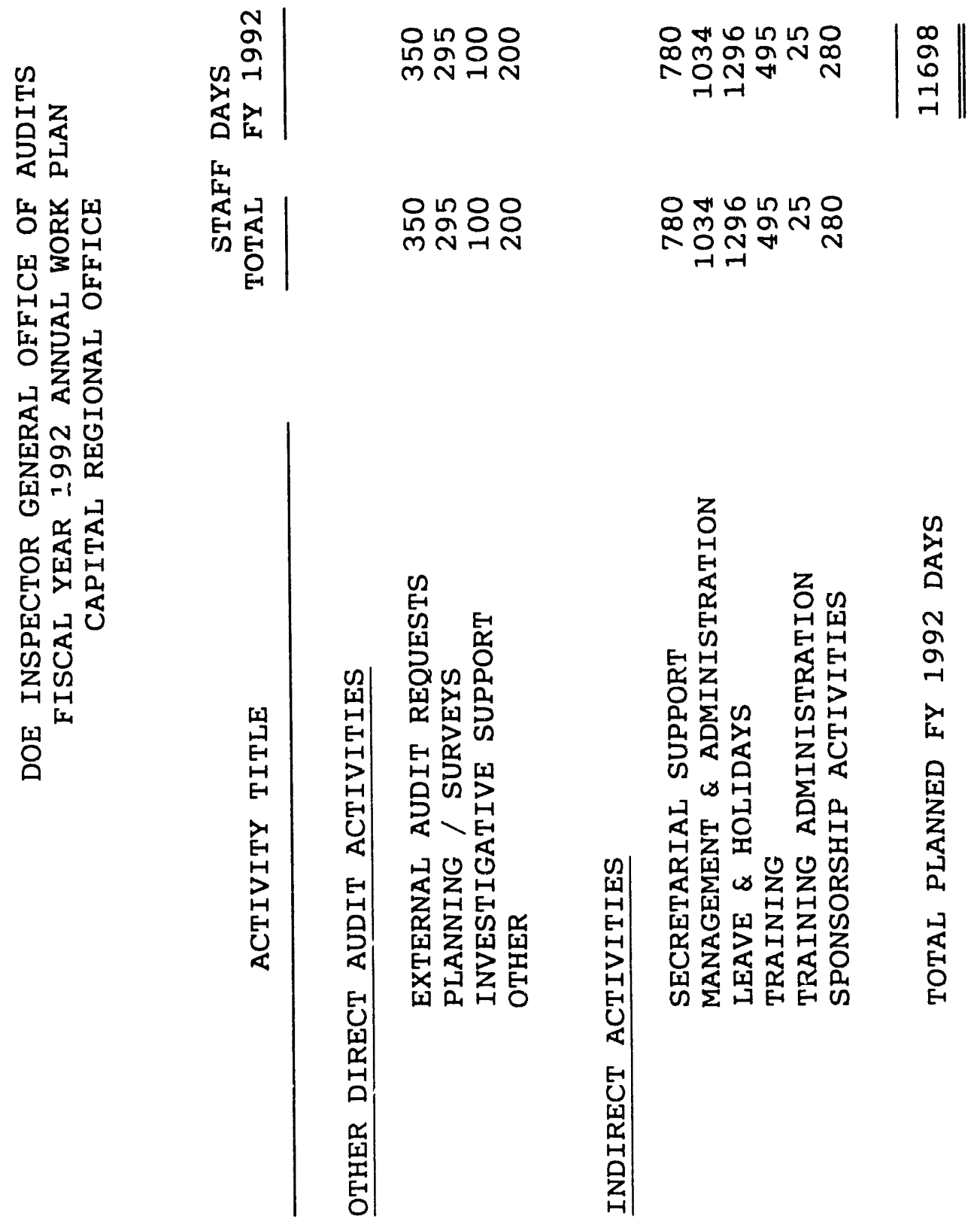




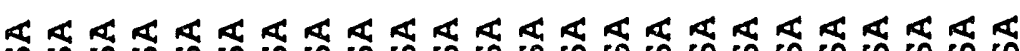

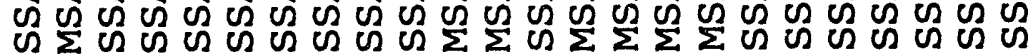

号罟舀|

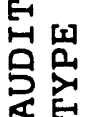

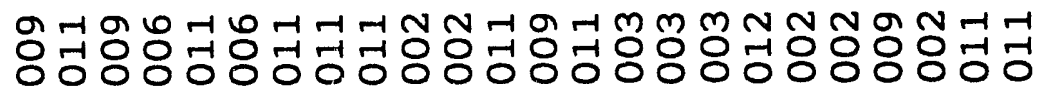

以

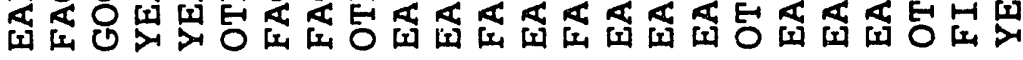

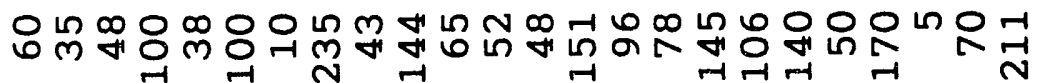

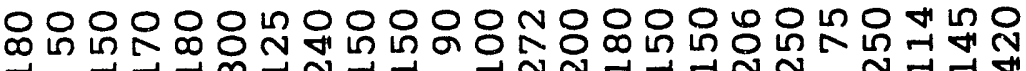

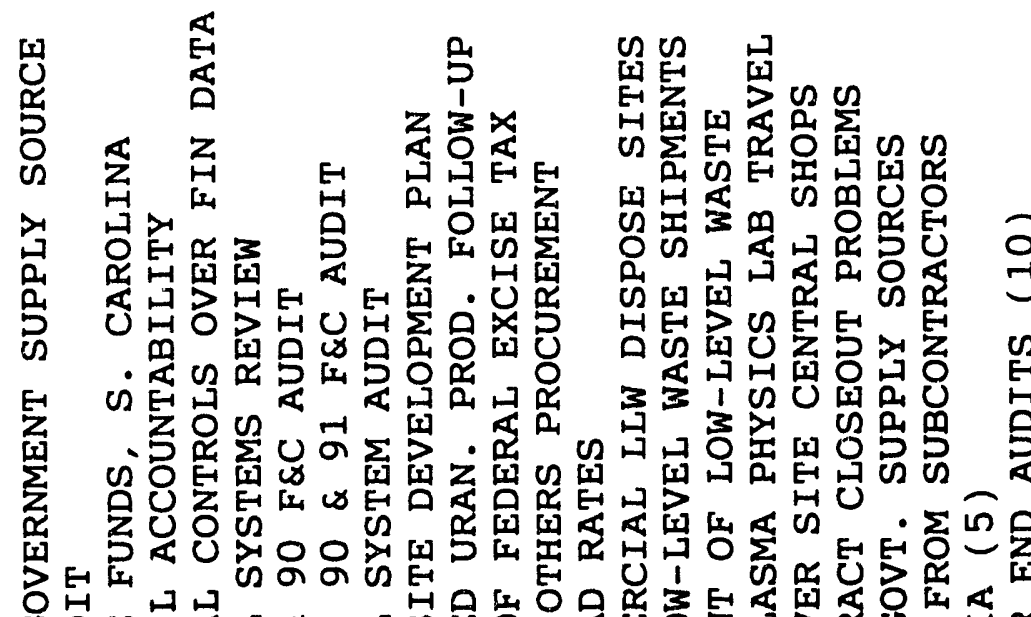

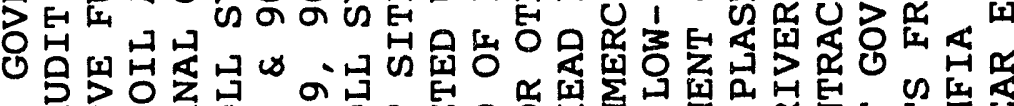

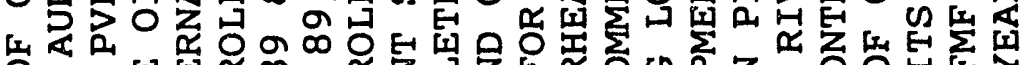

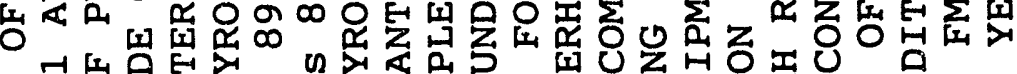

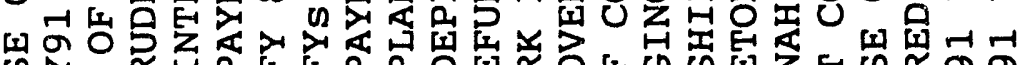

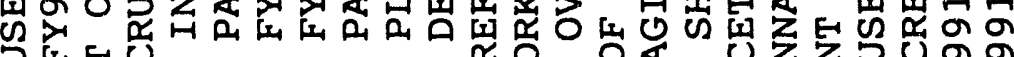
SEU E

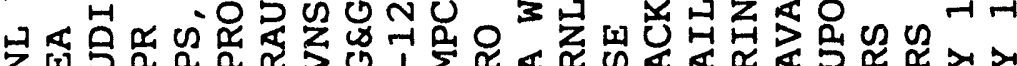

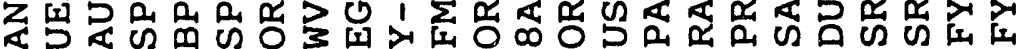

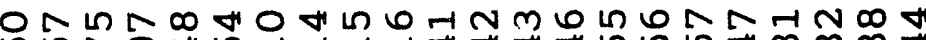

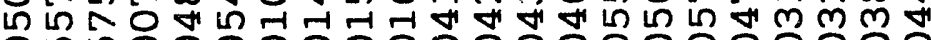

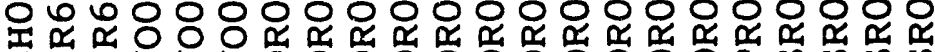

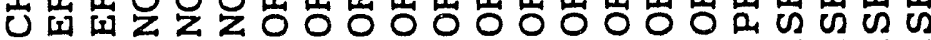

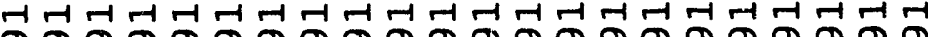

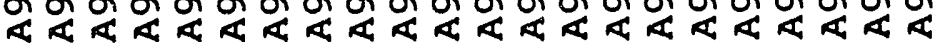




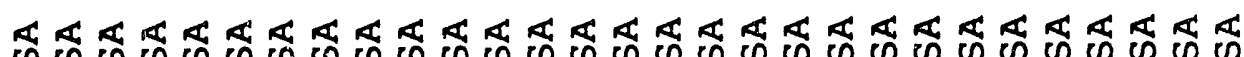

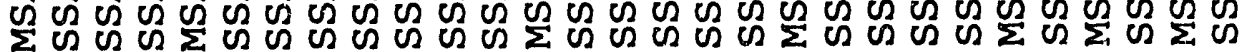

$4 \pi N n m \pi$ h

号罗芯

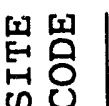

E-1

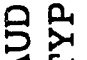

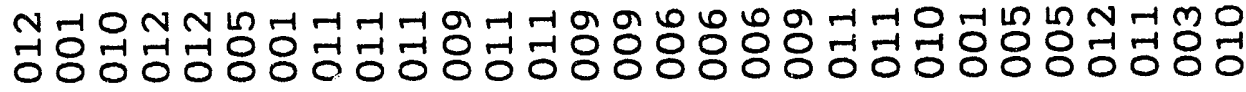

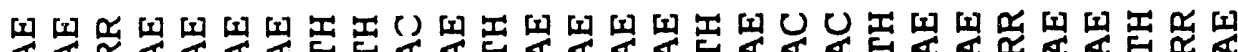

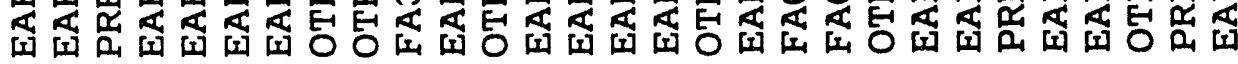

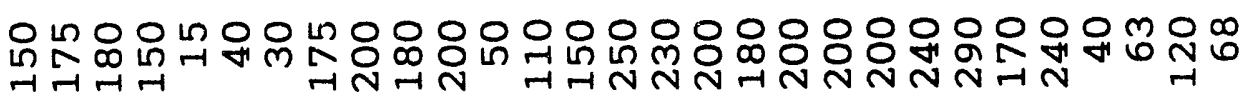

o n 000000000000000000000100000

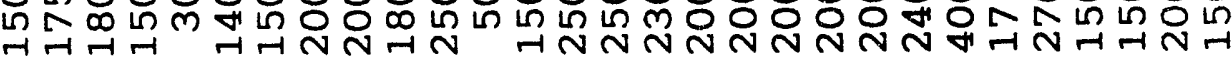

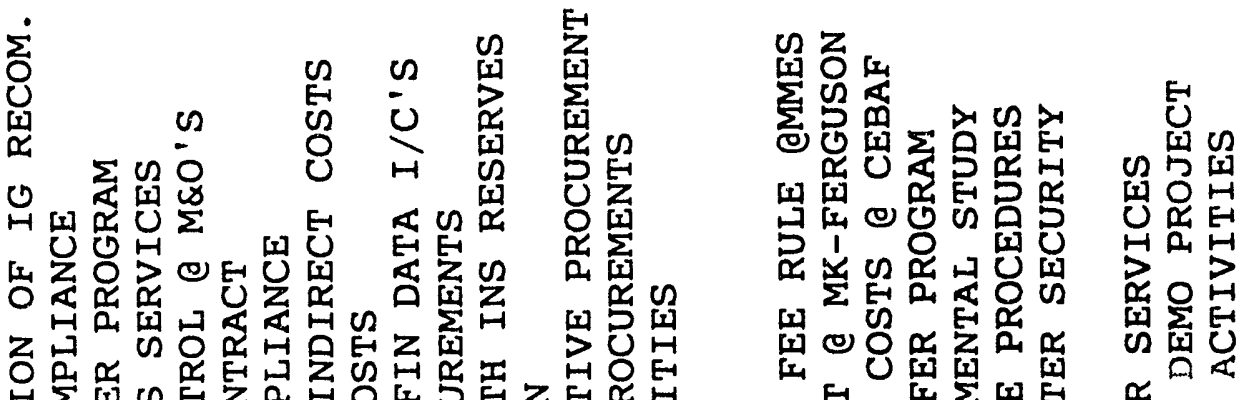

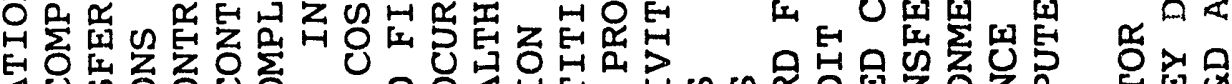

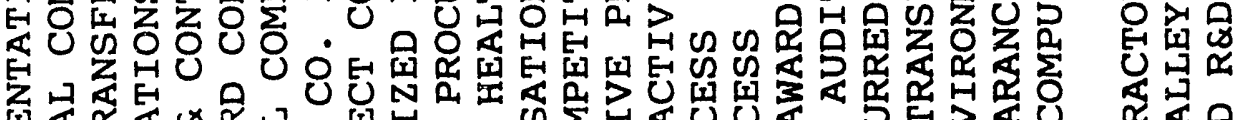

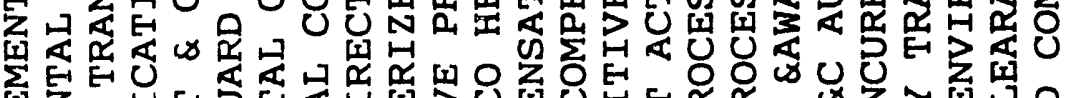

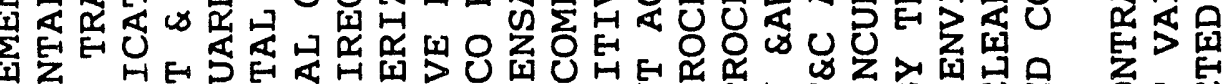

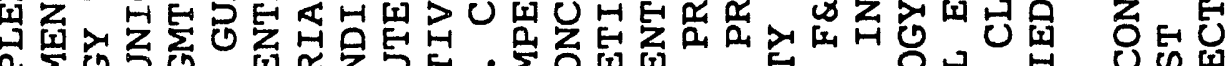

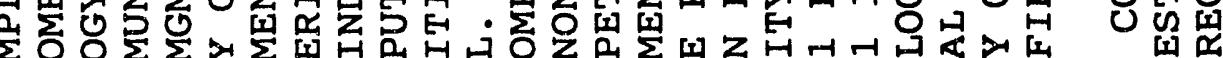

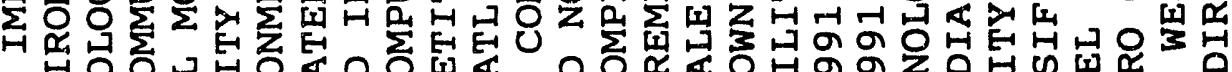

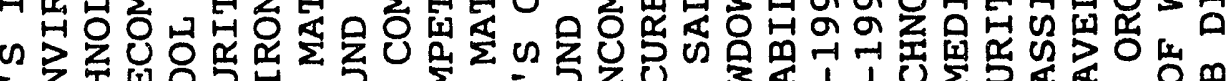

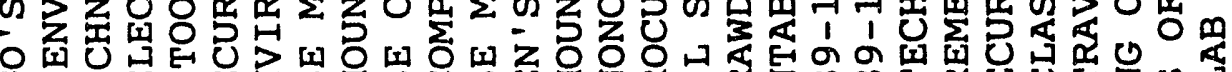

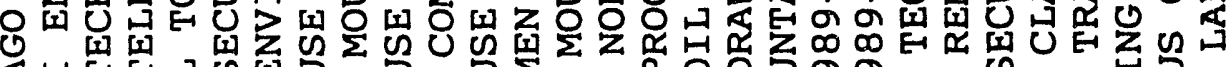

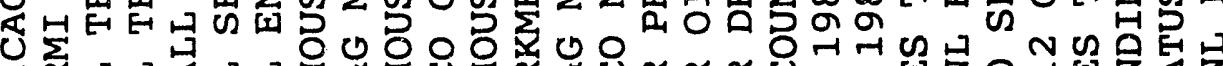

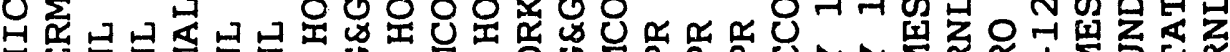

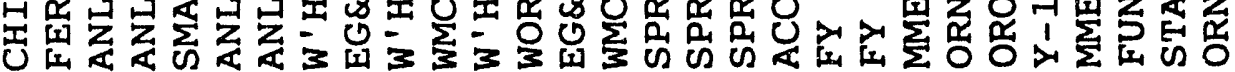

-1Mㄴ

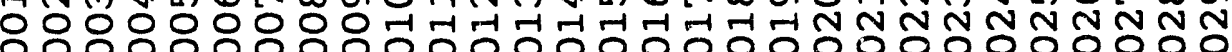

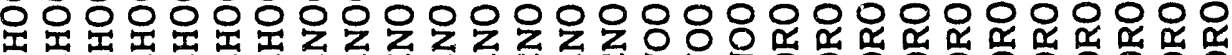
U U U U U U U U U U U U U U U U

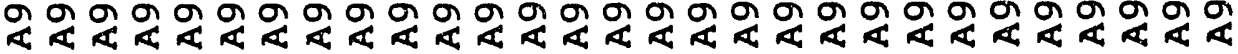



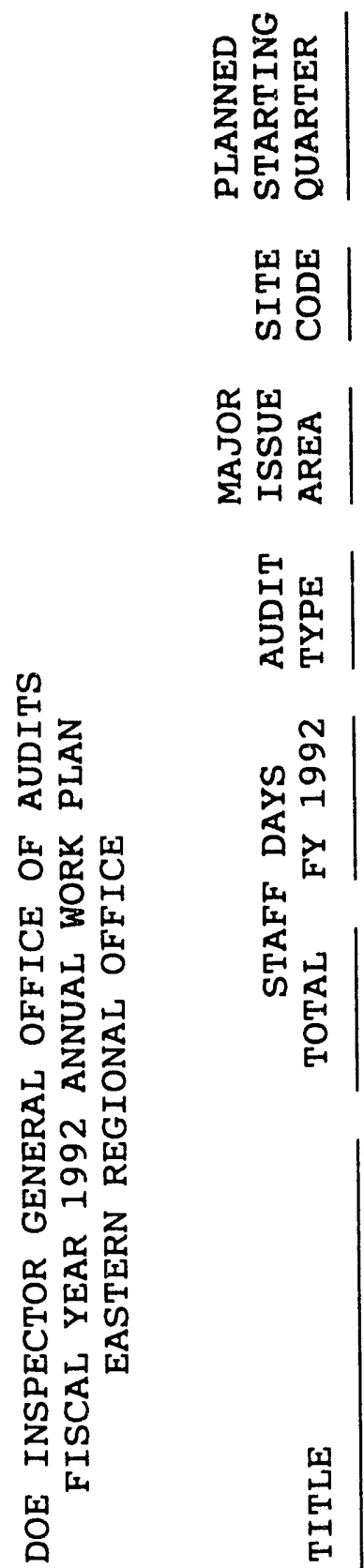

$A \pi n$ An

荡崖|

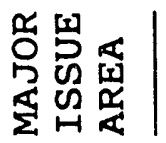

势罚|

至|



舅舀

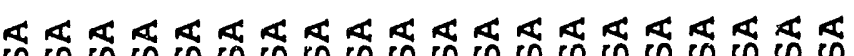

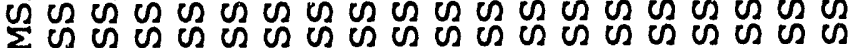

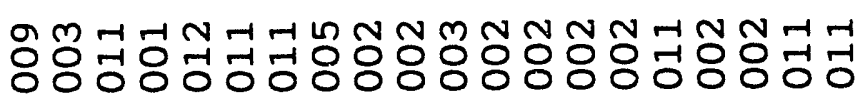

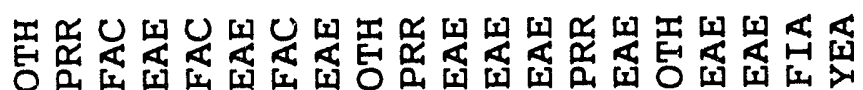

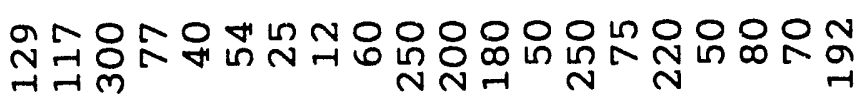

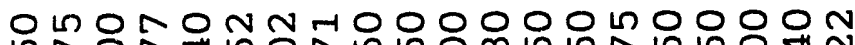

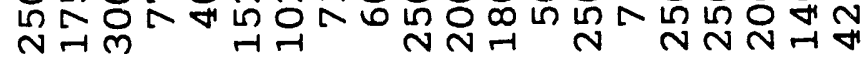

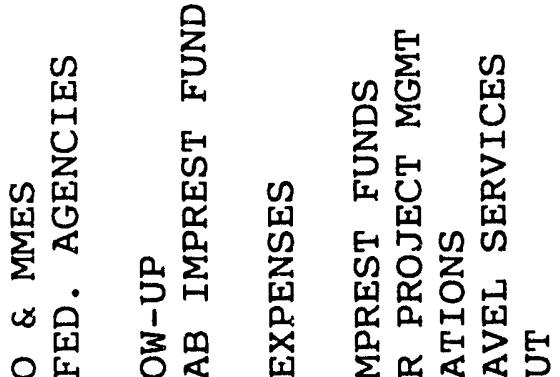

Uू

\$त्

鼠是突。

Z兒最

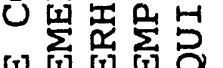

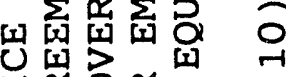

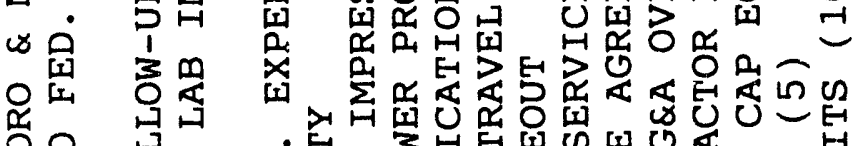

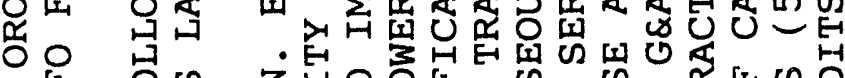

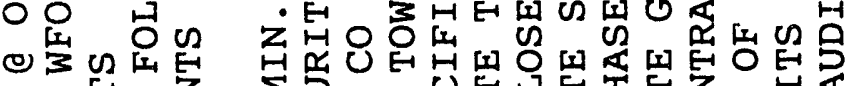

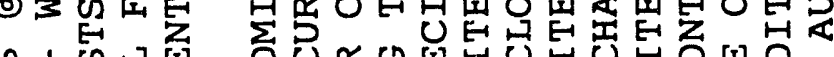

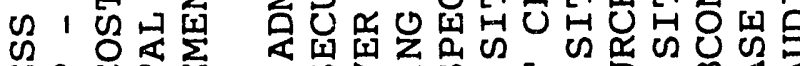

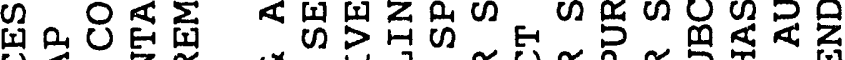

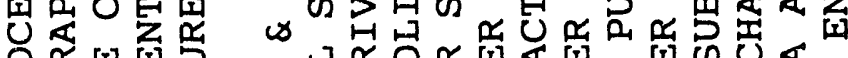

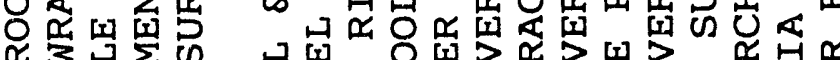

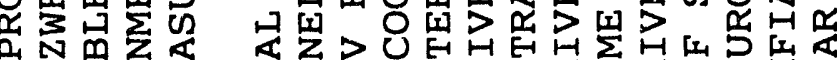

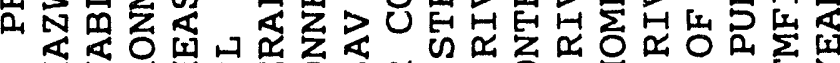

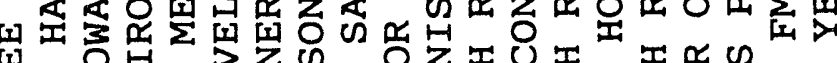
14

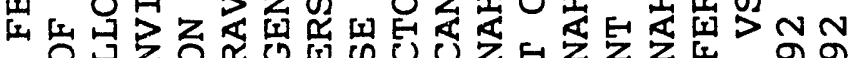

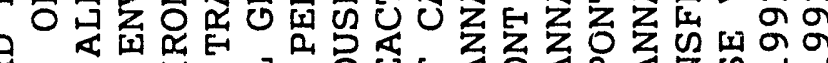

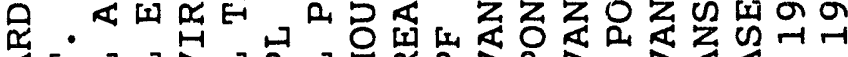

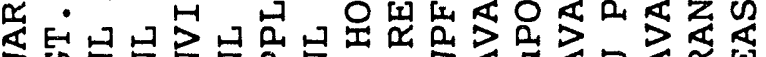

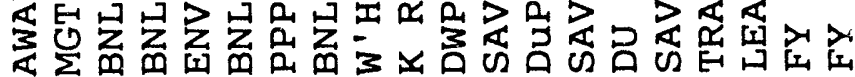

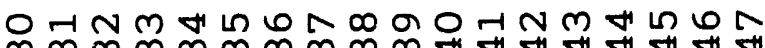

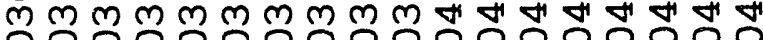
우순

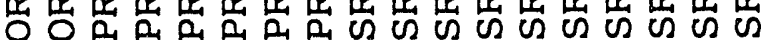
N N N N N N N NNNNNNNN

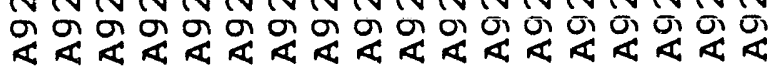



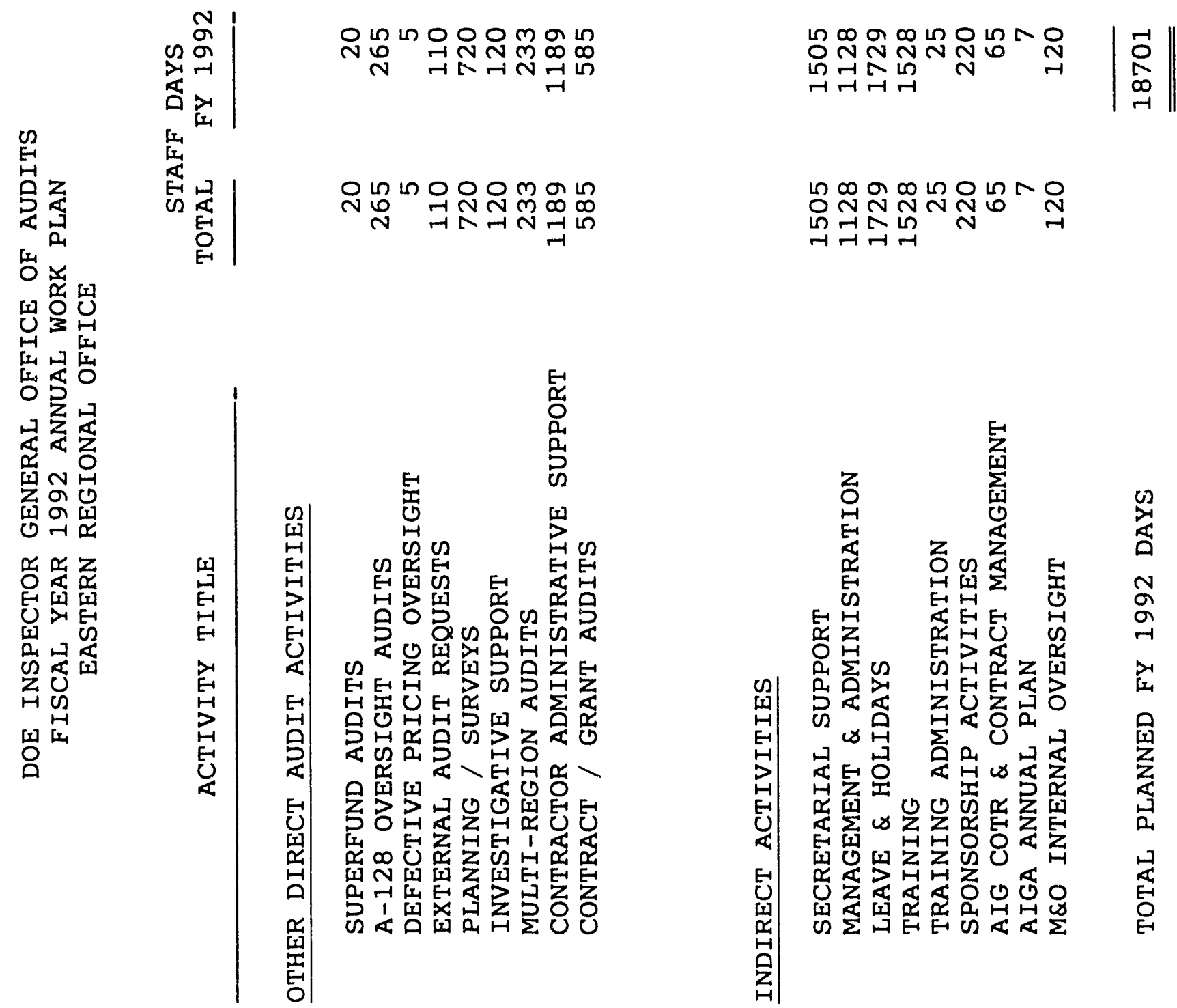


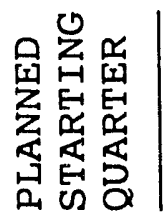

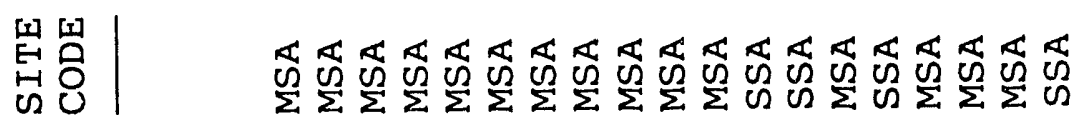

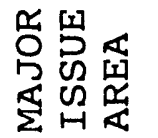

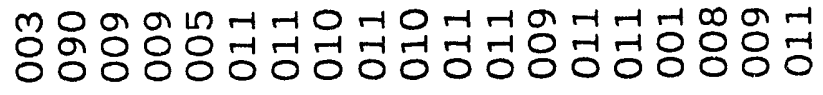

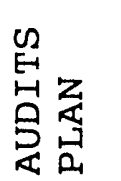

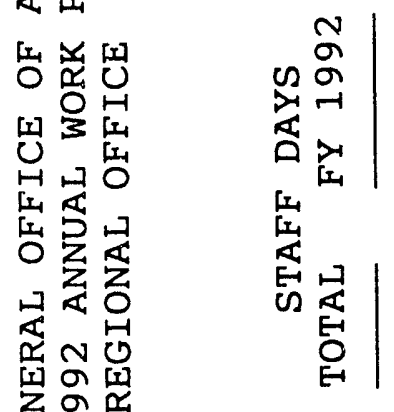

$z_{01}$ 正

님

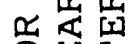

$\mathrm{O}_{-1} \mathrm{E}$

U

미

出

$Z$ @

[1

ำ
苔四

$\mid$

是点点

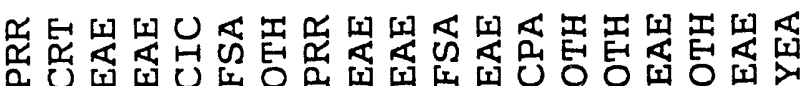

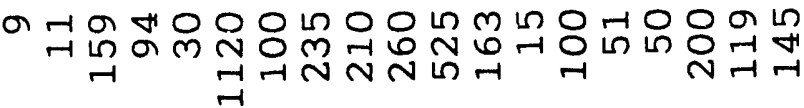

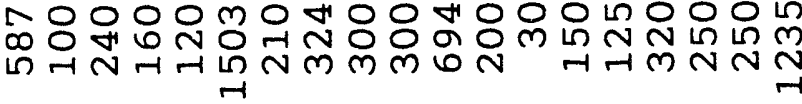

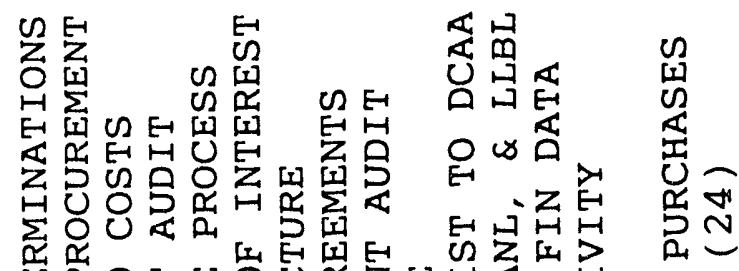

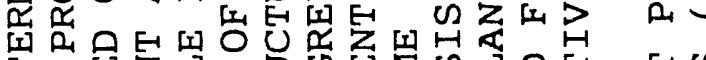

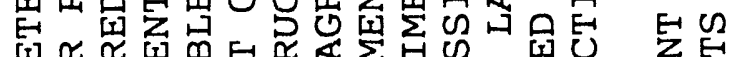

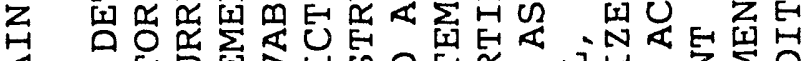

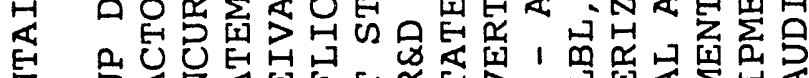

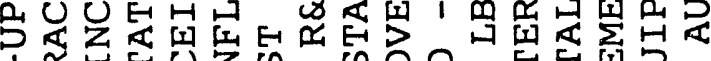

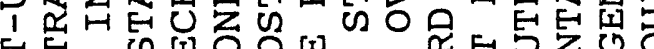

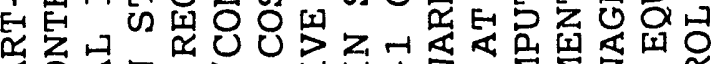

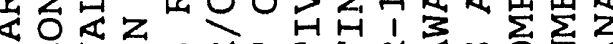

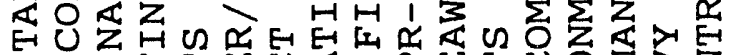

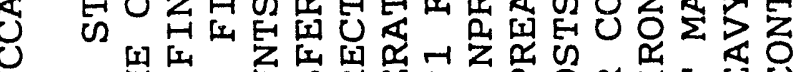

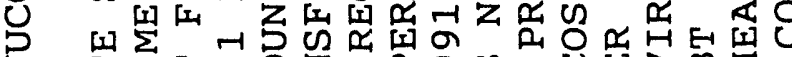

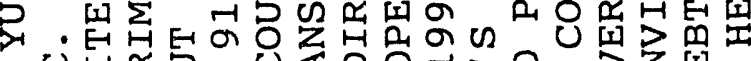

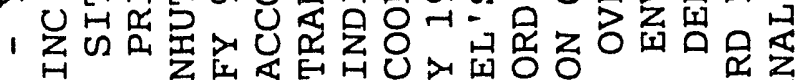

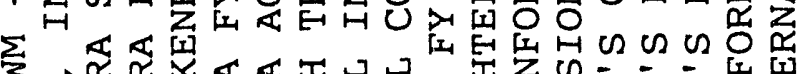

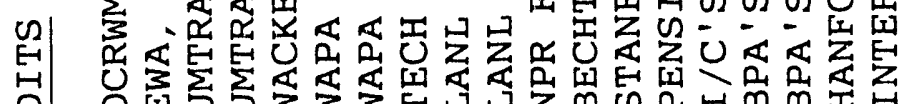

ט

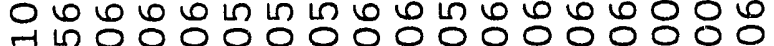

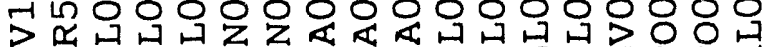

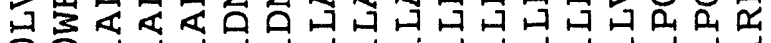
О૦

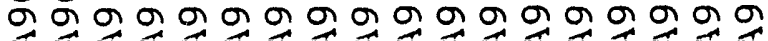
स 


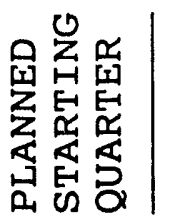

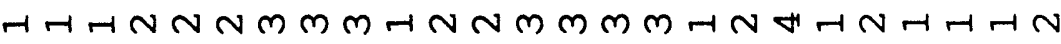

宸器

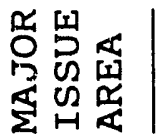

\section{总蛋}

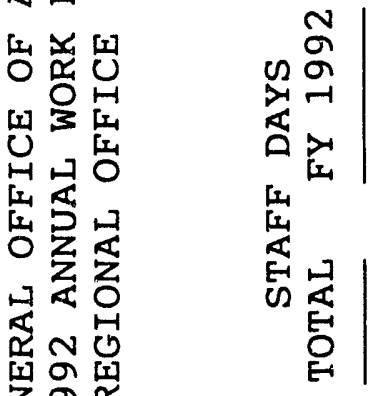

点
0 [

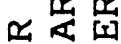

웃

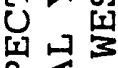

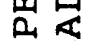

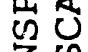

H

政

崌

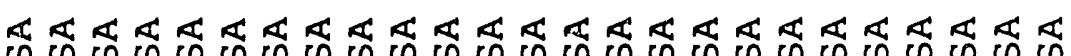

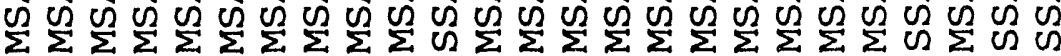

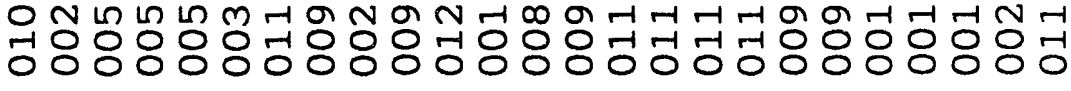

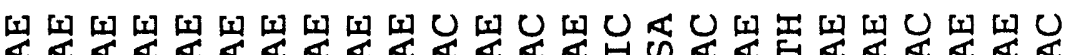

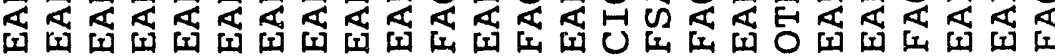

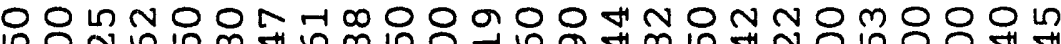
约

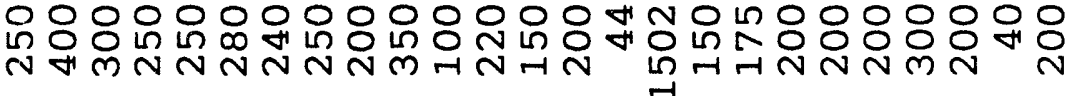

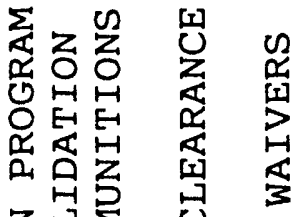

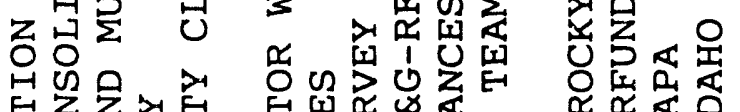

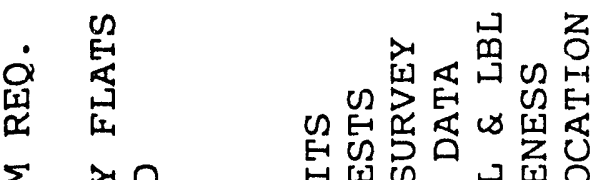

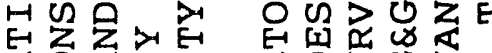

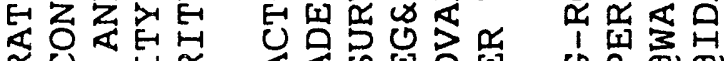

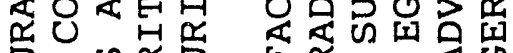

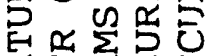

足

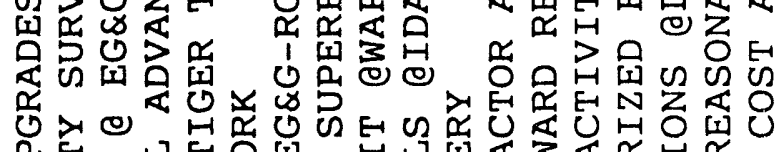

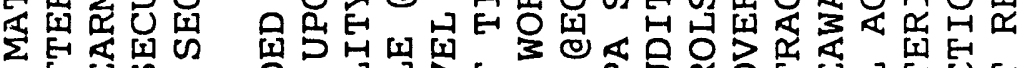

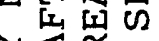

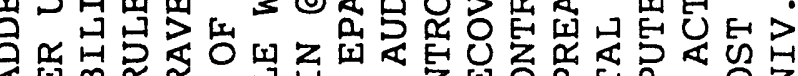

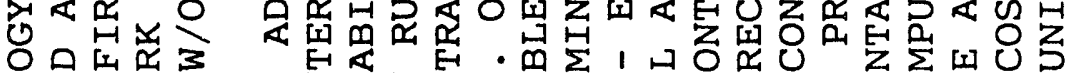

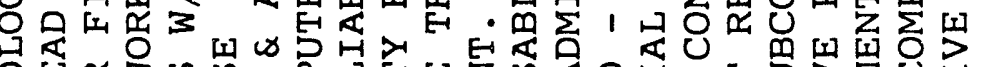

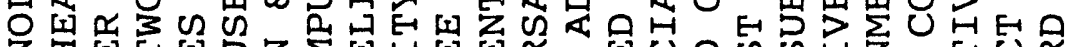

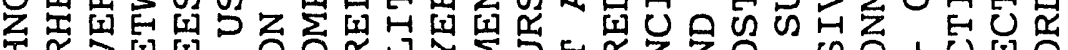

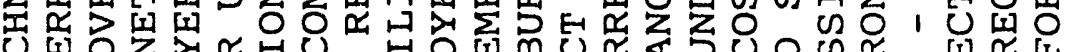

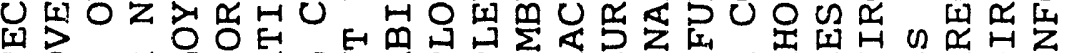
四

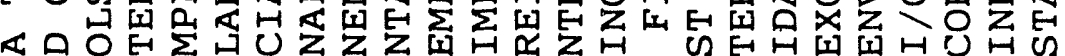

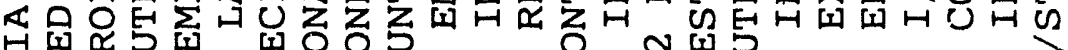

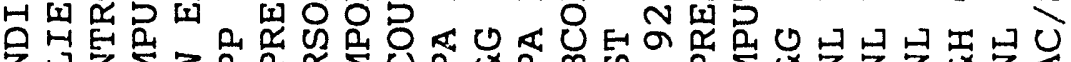

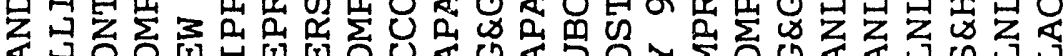

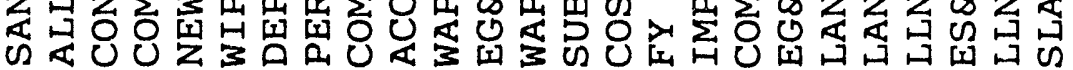

-1NM

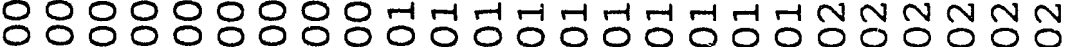

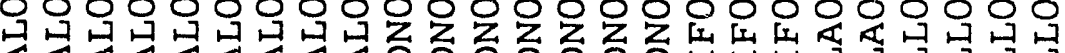

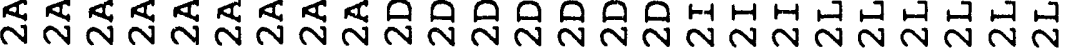

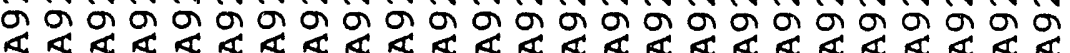




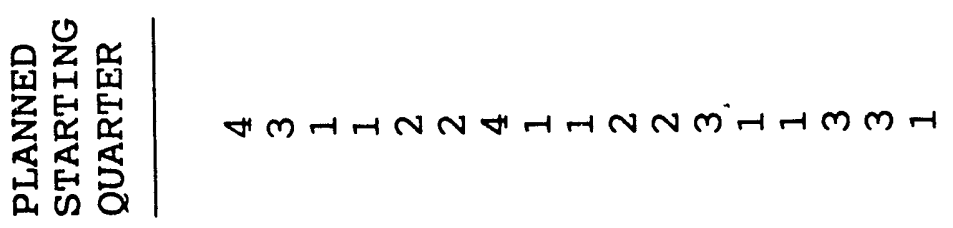

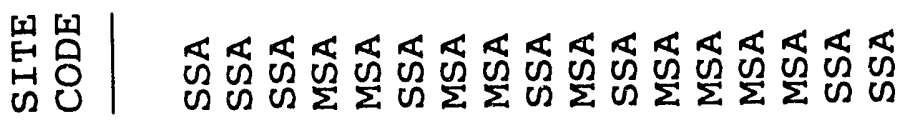

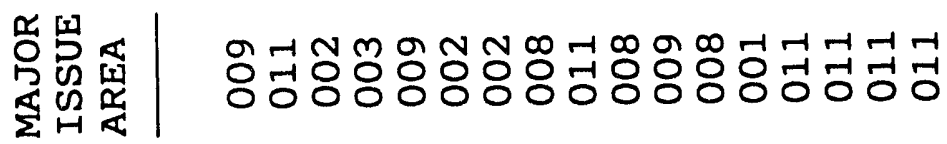

虽z

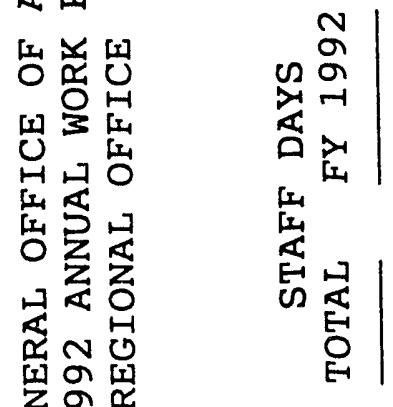

呂 बू

(1)

$\propto$ 号 品

E II

$\bigcup_{1 \rightarrow 1} \rightarrow \frac{[1]}{3}$

مा

is

Z

ำ

à

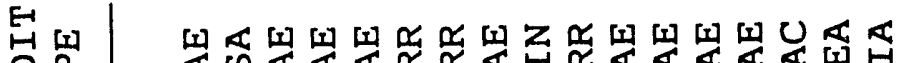

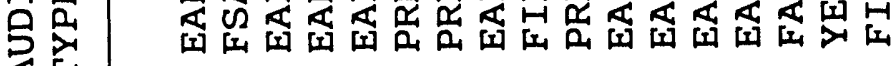

눈 N

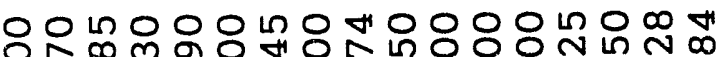
mo

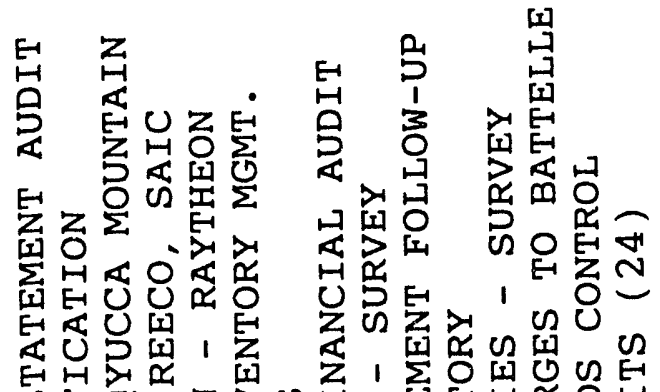

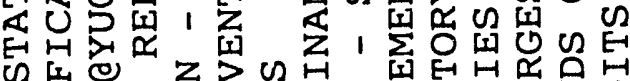

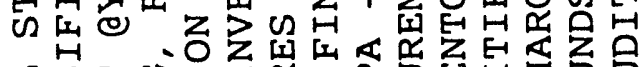

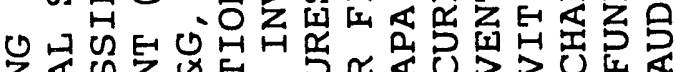

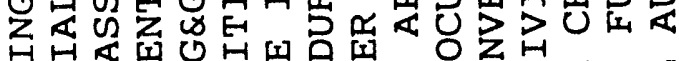

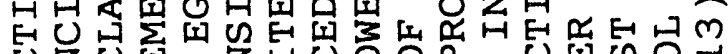

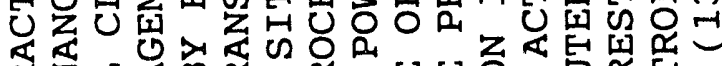

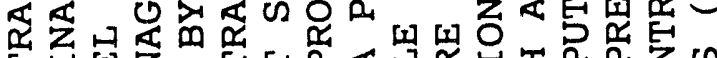

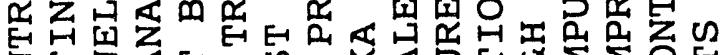

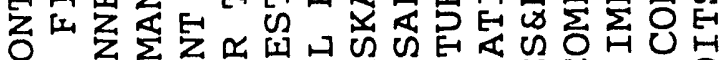

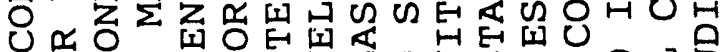

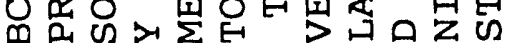

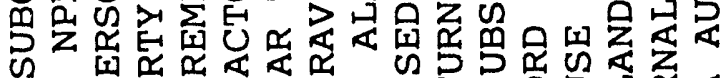
山

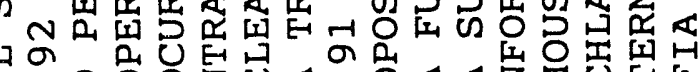

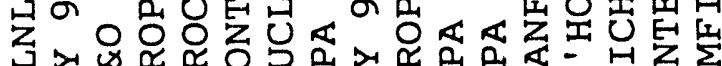

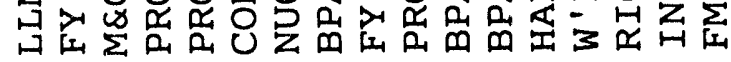

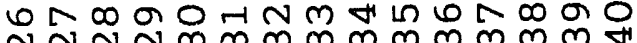
NNNNMMMMmMMMM

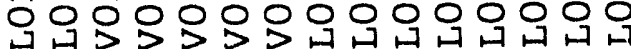

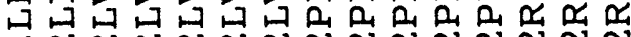
ก กัก กัก ก ก ก ก

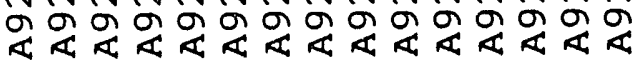




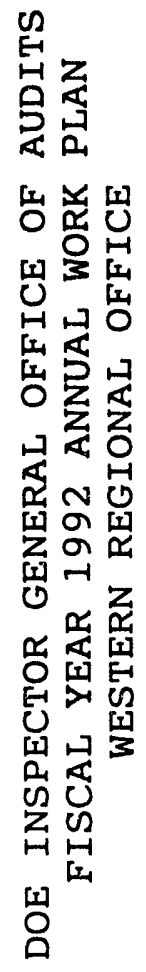

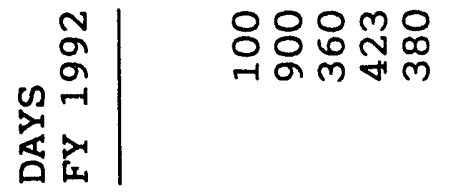
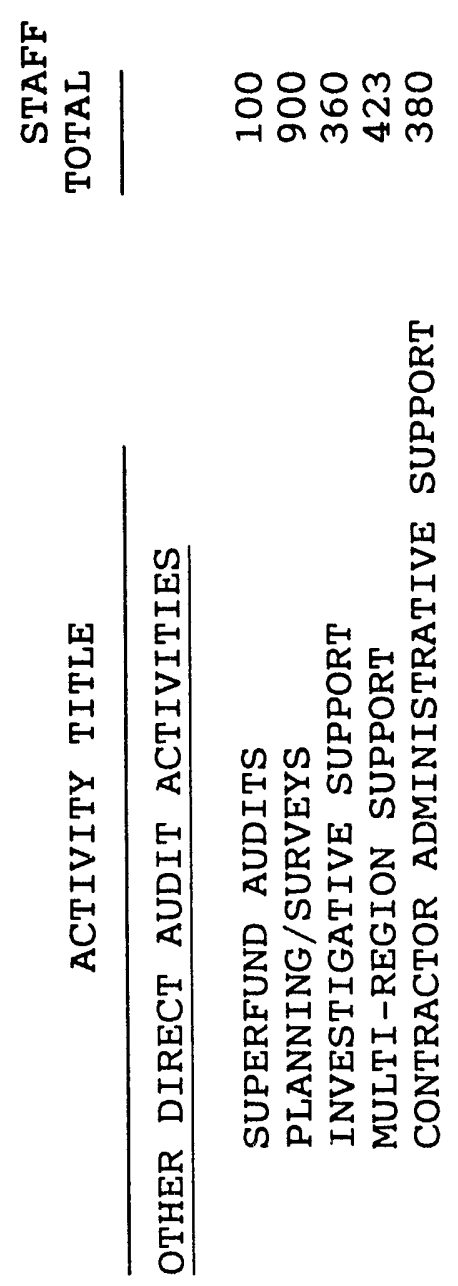

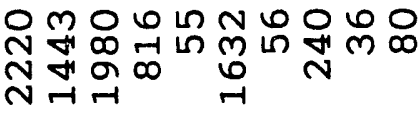

$\left|\begin{array}{l}-1 \\ \infty \\ n \\ N\end{array}\right|$

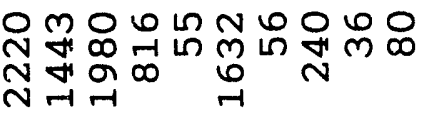

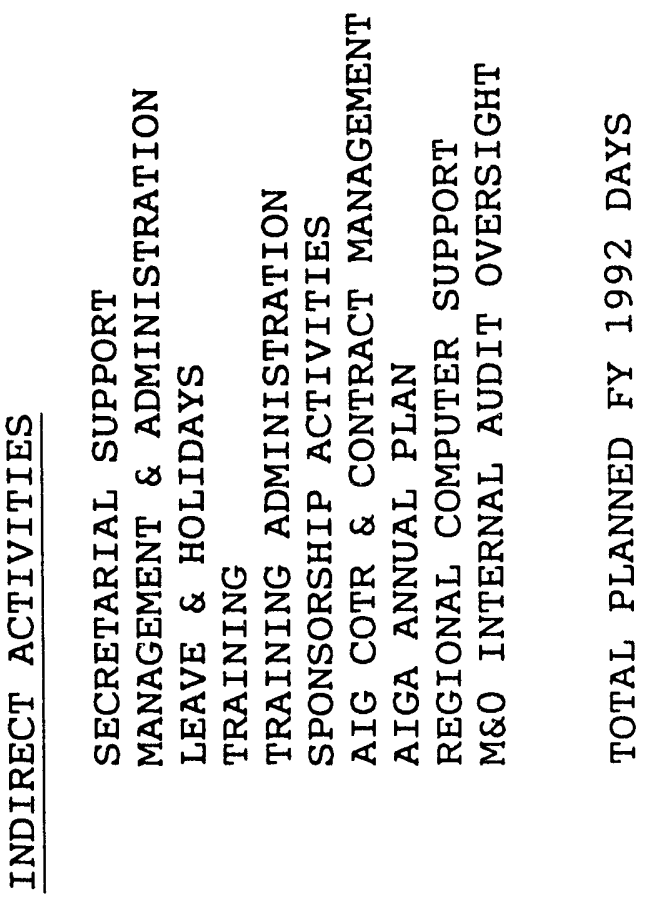




\section{DOE INSPECTOR GENERAL OFFICE OF AUDITS FISCAL YEAR 1992 ANNUAL WORK PLAN LIST OF ABBREVIATIONS}

ABBREVIATION

ADP

AIG

ANL

APA

BNL

BPA

BPS

CEBAF

CIC

CPA

DCAA

DOE

DWPF

EAE

EG\&G

EPA

ES\&H

FAC

FERC

FERMI

FIA

FIN

FMFIA

FSA

FY

G\&A

GAO

GEND

GOO

HAZWRAP

$I / C$

IG

LANL

LBL

LLNL

LLW

M\&O

MMES

MRA

MRS

\section{DEFINITION}

\author{
Automatic Data Processing \\ Assistant Inspector General \\ Argonne National Laboratory \\ Alaska Power Administration \\ Brookhaven National Laboratory \\ Bonneville Power Administration \\ Boeing Petroleum Services \\ Continuous Electron Beam Accelerator Facility \\ Cost Incurred Audit \\ Contract Preaward Audit \\ Defense Contract Audit Agency \\ Department of Energy \\ Defense Waste Processing Facility \\ Economy and Efficiency Audit \\ EG\&G Energy Measurement Systems \\ Environmental Protection Agency \\ Environment, Safety and Health \\ Financial and Compliance Audit \\ Federal Energy Regulatory Commission \\ FERMI National Accelerator Laboratory \\ FMFIA Audit \\ Financial Audit \\ Federal Managers' Financial Integrity Act \\ Financial Statement Audit \\ Fiscal Year \\ General and Administrative \\ General Accounting Office \\ General Electric Nuclear Division \\ Grant Audit \\ Hazardous Waste Remedial Action Program \\ Internal Control \\ Inspector General \\ Los Alamos National Laboratory \\ Lawrence Berkeley Laboratory \\ Lawrence Livermore National Laboratory \\ Low-Level (radioactive) Waste \\ Management and operating (contractor) \\ Martin Marietta Energy Systems \\ Multi-Region Audit \\ Monitored Retrievable Storage
}


M\&O

MMES

MRA

MRS

MSA

NES

NPR

OCRWM

OIG

ORAU

ORNL

ORO

OTH

PMA

PPPL

PRR

$R \& D$

REECO

RF

SAIC

SEPA

SLAC

SPR

SPRO

SRS

SSA

SSC

SWPA

UEA

UMTRA

VANEA

WAPA

WFO

W' HOUSE

WIPP

WMCO

WVNS

YEA
Management and operating (contractor)

Martin Marietta Energy Systems

Multi-Region Audit

Monitored Retrievable Storage

Multi-Site Audit

National Energy Strategy

Naval Petroleum Reserve

Office of Civilian Radioactive

Waste Management

office of Inspector General

Oak Ridge Associated Universities

Oak Ridge National Laboratory

Oak Ridge office

Other

Power Marketing Administration

Princeton Plasma Physics Laboratory

Program Results Audit

Research and Development

Reynolds Electical and Engineering Co., Inc.

Rocky Flats (facility)

Science Applications International Corporation

Southeastern Power Administration

Stanford Linear Accelerator

Strategic Petroleum Reserve

Strategic Petroleum Reserve office

Savannah River site

Single-Site Audit

Superconducting Super Collider

Southwestern Power Administration

Uranium Enrichment Activities

Uranium Mill Tailings Remedial Action Project

Voucher Accounting for Net Expenditures Accrued

Western Area Power Administration

Work-For-Others

Westinghouse

Waste Isolation Pilot Plant

Westinghouse Materials Company

West Valley Nuclear Site

Year-End Audit 
DOE INSPECTOR GENERAL OFFICE OF AUDIT

FISCAL YEAR 1992 ANNUAL WORK PLAN MAJOR PROGRAM AREA CODES

1

2

3

4

5

6

7

8

9

10

11

12
ENVIRONMENT, SAFETY \& HEALTH

WEAPONS PROGRAM

NUCLEAR WASTE DISPOSAL

NAVAL REACTORS

SAFEGUARDS \& SECURITY

STRATEGIC PETROLEUM RESERVE

SUPERCONDUCTING SUPER COLLIDER

POWER MARKETING ADMINISTRATIONS

PROCUREMENT \& GRANTS MANAGEMENT

EXPANSION OF LABORATORY MISSIONS

FINANCIAL MANAGEMENT

DETERRENTS 

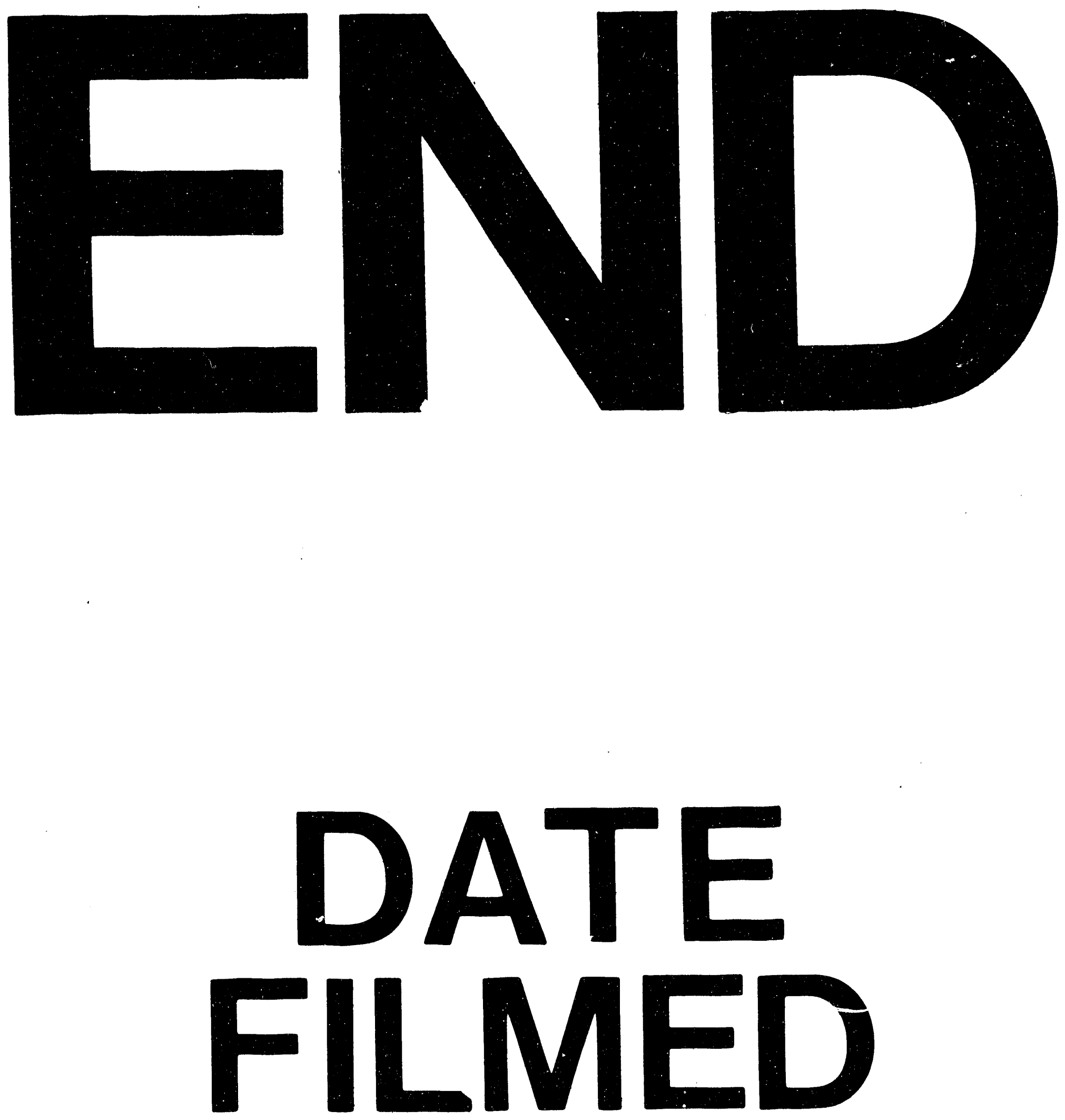

I

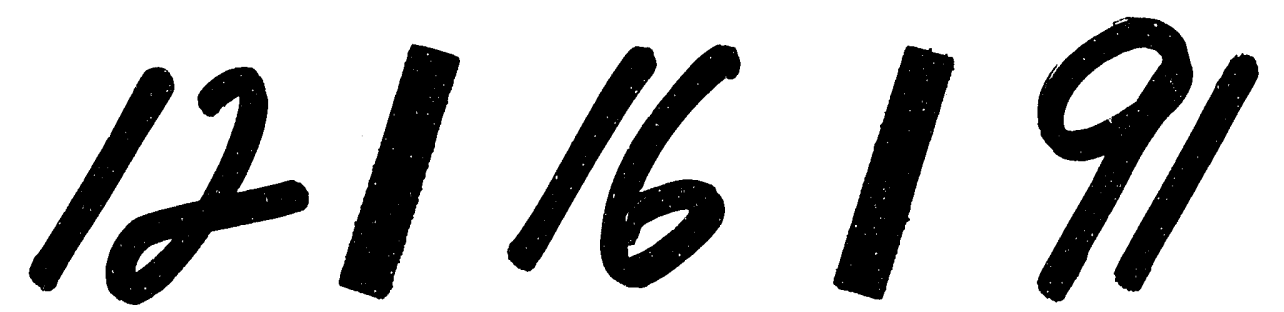

